\title{
Combined effects of climate change and dam construction on riverine ecosystems
}

\author{
Mijke van Oorschot ${ }^{\mathrm{a}, \mathrm{b}, *}$, Maarten Kleinhans ${ }^{\mathrm{a}}$, Tom Buijse ${ }^{\mathrm{b}}$, Gertjan Geerling ${ }^{\mathrm{b}, \mathrm{c}}$, Hans Middelkoop ${ }^{\mathrm{a}}$ \\ a Faculty of Geosciences, Universiteit Utrecht, PO Box 80115, 3508 TC Utrecht, The Netherlands \\ b Deltares, Department of Freshwater Ecology and Water Quality, PO Box 177, 2600 MH Delft, The Netherlands \\ ${ }^{\mathrm{c}}$ Radboud University Nijmegen, Institute for Water and Wetland Research, Department of Environmental Science, PO Box 9010,6500 GL Nijmegen, The Netherlands
}

\section{A R T I C L E I N F O}

\section{Keywords:}

Climate change

Dams

Flow alteration

Bio-geomorphology

River morphodynamics

Riparian vegetation

\begin{abstract}
A B S T R A C T
River morphology and riparian vegetation continuously adapt to changing discharge conditions, which makes it a challenge to distinguish long-term development driven by natural discharge variation from the impacts of flow alteration due to climate change and due to dams. The aim of this study was to investigate how such flow alterations affect bio-geomorphological processes and habitat suitability of several fluvial plant and animal species. This is done with a numerical model representing dynamic interactions between morphodynamic processes and riparian vegetation coupled to habitat suitability models of fluvial species. We compared a control run with natural flow regime to altered flow for two scenarios with different dam operating regimes, two scenarios with climate change, and for combinations of dams and climate change. Results show that flow stabilization leads to incision, acute reduced seedling recruitment and decline of riparian vegetation. Climate change generates a gradual response, where high flow extremes counteract an otherwise reduced seedling recruitment of pioneer vegetation, while drying reduces riparian vegetation recruitment and causes vegetation shifts towards lower elevations on the floodplain. Modelled habitat availability for facilitated plant and animal species declines most when the synchronicity between critical life history events and habitat requirements is disrupted by altered flow conditions, with opposite effects for different species. Dynamic interactions between bio-geo-morphological processes with somewhat different characteristic timescales create non-linear and adaptive behaviour of morphology, habitat patterns and facilitated species habitat. This implies that only models that include bio-geomorphological feedbacks can forecast impacts of multiple flow alteration pressures, whereas addition of singlepressure regime effects is overly simplistic.
\end{abstract}

\section{Introduction}

Humans have been altering river systems for centuries to fulfill their water needs and for protection against floods. Dams have been constructed to secure water supply, regulate river flow for navigation and to generate power. Consequently, the flow regime of many rivers has been dramatically altered from their natural flow regime (Dynesius and Nilsson, 1994; Nilsson et al., 2005). Flow alteration by dams can affect the magnitude, timing and duration of high and low flows (Clarke et al., 2008). In addition to these direct human alterations, climate change is beginning to affect the hydrological regime as well. Multiple climate models forecast a general trend towards lower discharges and an increase of precipitation in winter and spring in Europe (Dankers and Feyen, 2008; Van Vliet et al., 2013). Both these direct regulation-associated and climate driven alterations will likely continue to affect rivers for the coming decades, potentially having dramatic and unpredictable impacts on their morphodynamics and associated ecosystems.

Riparian species closely depend on river flow and have adapted their life-history processes to flow regimes (Karrenberg et al., 2002). Consequently, flow regimes and associated bio-morphological interactions determine the distribution pattern of riparian species. Therefore, alteration of the flow regime inevitably leads to shifts in riparian ecosystem dynamics.

Changing timing of peak flows can decrease the colonization success of riparian plant species when it results in a mismatch between the seasonal flow and the timing of seed release (Poff et al., 2010). A decrease in high flows reduces the connectivity of the main channel to the floodplain, thereby restricting movement of specific fish and macroinvertebrate species between different habitat types that are essential to complete their life-cycle (Rolls et al., 2012). Furthermore, a decrease in inter-annual discharge variation will lead to a decline in richness of

\footnotetext{
* Corresponding author at: Deltares, Department of Freshwater Ecology and Water Quality, PO Box 177, 2600 MH Delft, The Netherlands

E-mail address: mijke.vanoorschot@deltares.nl (M. van Oorschot).
} 
riparian species and fish species (Poff et al., 2010). Less frequent overbank flooding due to, for instance, dam construction may lead to an increase of vegetation and vegetation development within or adjacent to the river channel (Williams and Wolman, 1984; Dolores Bejarano et al., 2011), aging of riparian vegetation (Azami et al., 2004), reduced recruitment success of riparian trees, and eventually a decline in softwood forest extent (Rood and Mahoney, 1990, 1995; Polzin and Rood, 2000). Additionally, the riparian ecosystem can become more vulnerable to competing effects of invasive alien species that can faster and better adapt to new conditions than native species, e.g. invasive species that rapidly elongate their root systems to cope with dryer conditions after dam construction (Stromberg et al., 2007; McShane et al., 2015). Hydrological change also affects riparian ecosystems by rearranging the habitat mosaic through changes in river morphology (Nilsson and Svedmark, 2002). In turn, this influences the settlement locations of pioneer eco-engineering species and all other species depending on the conditions created by these engineering species (Williams and Wolman, 1984; Gurnell, 2014).

The bio-geomorphological response of rivers to impoundment by dams depends on a variety of factors, such as sediment load and grain size, dam operating regime, climatic region, type of vegetation and inherited channel form (Williams and Wolman, 1984). This large variability makes it difficult to predict the rate and sequence of changes in river morphology (Petts and Gurnell, 2005). There are some conceptual frameworks that generalize effects of dams in terms of changes in channel dimensions, roughness and slope due to changes in discharge and sediment load (Ward and Stanford, 1995; Petts and Gurnell, 2005). For instance, in rivers where discharge is strongly reduced, the channel width and channel conveyance are reduced (Petts and Gurnell, 2005). The time that is necessary for rivers to reach a new dynamic equilibrium after the flow alteration can range from less than 10 years in systems with high sediment loads and fast vegetation development to well over 200 years in environments that are less dynamic (Williams and Wolman, 1984). For instance, in an intermediate-sized meandering sand-bed river, Merritt and Cooper (2000) found channel narrowing in the first decade after dam construction followed by channel widening and vegetated mid-channel bars in subsequent years.

In contrast to the relatively extreme and acute effect of dams, climate change leads to a more gradual change in conditions depending on geographical location. Potential adverse effects of climate change for fish and macro-invertebrates are often attributed to altered chemical composition and increasing water temperature (Brucet et al., 2012; Mantyka-Pringle et al., 2014; Santiago et al., 2016). However, also changes in low flows and high flows can disrupt critical life history processes. For instance, lower flows reduce the available spawning and incubation habitat for salmon, while increased peak flows can destroy salmon eggs through scouring (Battin et al., 2007) and change the general abundance and community composition of fish and macro-invertebrates (Death et al., 2015). Yet, few studies have addressed the effects of climate change on riparian vegetation. In the case of more extreme events in high- as well as low flows, Mosner et al. (2015) predict a general decrease in habitat for hardwood forest and softwood forest in the River Rhine. Other studies involving climatic predictions with a general drying trend, predict a decrease in early succession phases and a trend towards aging of vegetation and replacement of softwood species with more drought-tolerant species (Rood et al., 2008; Stromberg et al., 2010; Rivaes et al., 2014).

Bio-geomorphological impacts of altered flow regimes are controlled by the interactions between vegetation and morphodynamics, which are non-linear and comprise both negative and positive feedbacks. In an intermediate-sized river where vegetation and morphodynamics regularly interact, vegetation density as well as vegetation location on the floodplain strongly influence the morphodynamics of the system (van Oorschot et al., 2016). Dense vegetation development reduces morphodynamic activity and can lead to avulsions, while more sparsely distributed vegetation leaves room for chute cut-offs and dynamic meandering, which locally cause vegetation mortality and at other locations creates new suitable sites for settlement (van Oorschot et al., 2016). Since vegetation and river pattern both adapt to altered discharge conditions, it is a challenge to distinguish effects of the natural discharge variation from the effect of climate change and dams (Petts and Gurnell, 2005).

This study aimed at determining and understanding how altered flow regimes affect bio-geomorphological processes and habitat suitability of representative fluvial plant and animal species and species groups. To this end, we tested effects of two types of flow alterations: acute flow alteration related to dam construction and gradual flow alteration caused by climate change as well as combinations of both pressures. This was done by simulating the bio-geomorphological interactions in a river stretch using a numerical model for morphodynamic processes that was dynamically linked with a model for vegetation colonization and growth processes. Although this coupled model is computationally expensive, it allows us to investigate the complex and dynamic bio-geomorphological patterns and dynamics that emerge on the timescale of decades. We ran in total 9 scenarios: a control, two different dam scenarios, two opposing climate scenarios and all combinations between dam and climate change scenarios. One dam scenario represented preservation of flow seasonality, the other completely reversed flow seasonality. The climate change scenarios comprise one with a general drying trend and one with increased low and high flows. All scenarios and combinations of scenarios were compared to a reference scenario with an unaltered, natural flow regime for evaluation of trends and changes in ecosystem response.

\section{Methods}

We conducted modelling for several flow alteration scenarios with a detailed hydro-morphological model coupled to our vegetation model, detailed below. The model represents intermediate-sized meandering rivers: this condition was chosen such that the surface cover is created by interacting fluvial morphodynamics and vegetation, and that neither dominate the resulting landscape in the reference situation. The scenarios are idealised in the sense that they represent typical conditions as found in the literature, but the scenarios are also realistic in the sense that we retained the natural discharge variability necessary for the expected settling, growth and mortality of the riparian tree species. Results for these scenarios were compared in vegetation age and cover properties. Furthermore, we applied habitat suitability rules for representative fluvial plant and animal species of several taxonomic groups to assess wider ecological implications of the changing river conditions and landscapes.

\subsection{Eco-morphodynamic model}

We loosely based our modelled river stretch on the Allier River in France, which is a medium sized, dynamic meandering gravel bed river of which the morphodynamics and vegetation have been well documented over the last years (Geerling et al., 2006; Kleinhans and van den Berg, 2011; Van Dijk et al., 2014). The eco-morphodynamic model contains the morphodynamic model Delft3D for numerical calculation of depth-averaged flow velocities and bed level updates (see Lesser et al., 2004; Schuurman et al., 2013, for details on morphodynamic equations and processes) and an interactively coupled riparian vegetation model based on van Oorschot et al. (2016), containing vegetation colonization, growth, prediction of hydraulic resistance and mortality through flooding, desiccation, uprooting, scour and burial. Initial model settings and parameterization of hydro-morphodynamic model parameters, except the discharges, were similar to those described in van Oorschot et al. (2016). The vegetation model from van Oorschot et al. (2016) has been updated and re-calibrated at several points. The current model version calculates and updates vegetation growth and mortality in two-weekly time steps, as opposed to once a year in the 


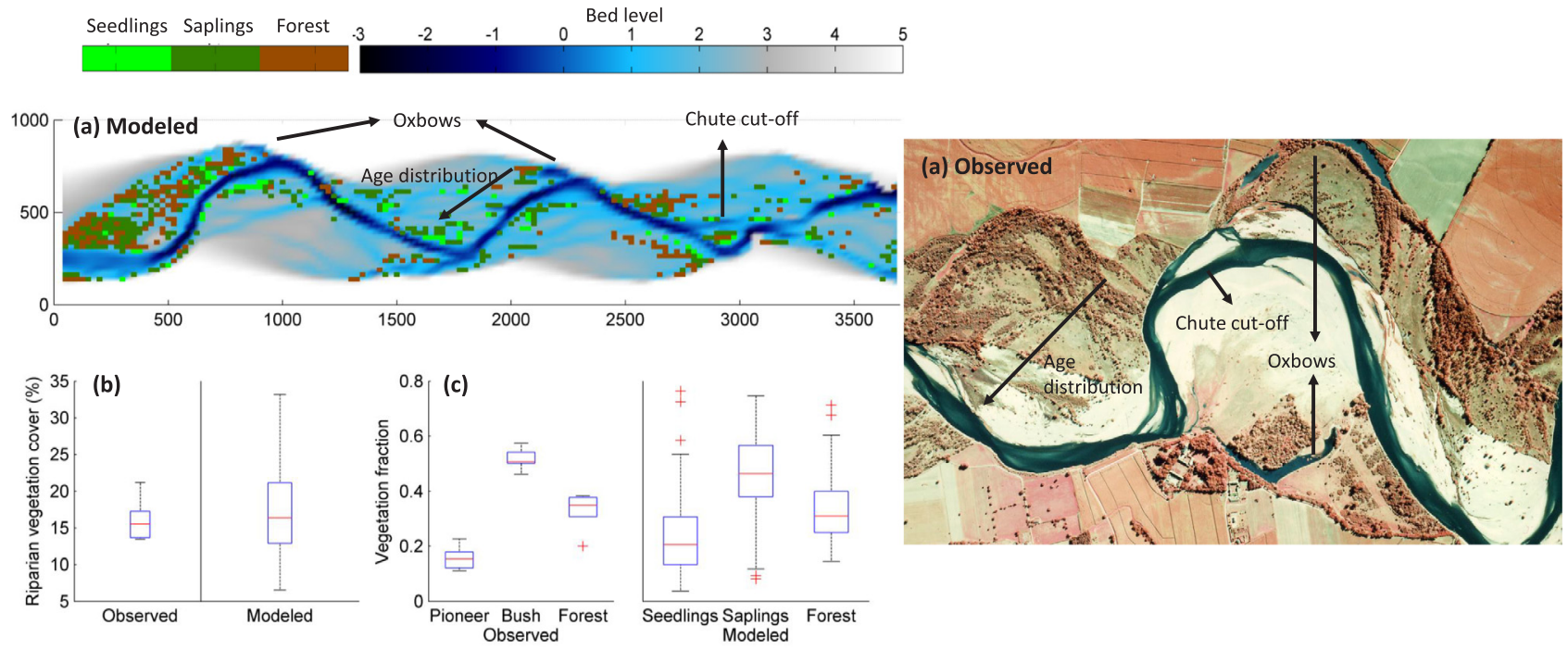

Fig. 1. Comparison of modelled and observed patterns and statistics for vegetation and river morphology. a) Comparison of vegetation patterns and river morphology between the model simulation with natural discharge conditions at simulation year 100 (real year 1992), which serves as the starting point for all the scenarios. The model produced similar morphological features and vegetation zonation as observed in aerial photos of the Allier River. Oxbow lakes are formed by meander migration and meander bends are periodically cut off. Older vegetation is found on the higher parts of the floodplain near oxbow lakes or at the upstream side of meander bends, while younger vegetation is found closer to the channel. b) Total riparian vegetation cover expressed as the sum of observed aerial cover of pioneer, bush (averaged over open and closed) and forest (averaged over open and closed) from Geerling et al. (2006) for 6 years, compared to the total modelled vegetation cover over model year 50 (real year 1942) to the end of the simulation at year 209 (real year 2100). The median vegetation cover is similar, but the model shows a larger spread. c) Age ratio of observed aerial vegetation cover compared to the modelled cover of seedlings, saplings (2-10 yrs) and forest (older than 10 yrs) over model year 50 (real year 1942) to the end of the simulation at year 209 (real year 2100). The modelled age ratio shows a similar range as the observed age ratio, showing the highest fraction of saplings/bush and the lowest fraction of seedlings/pioneers.

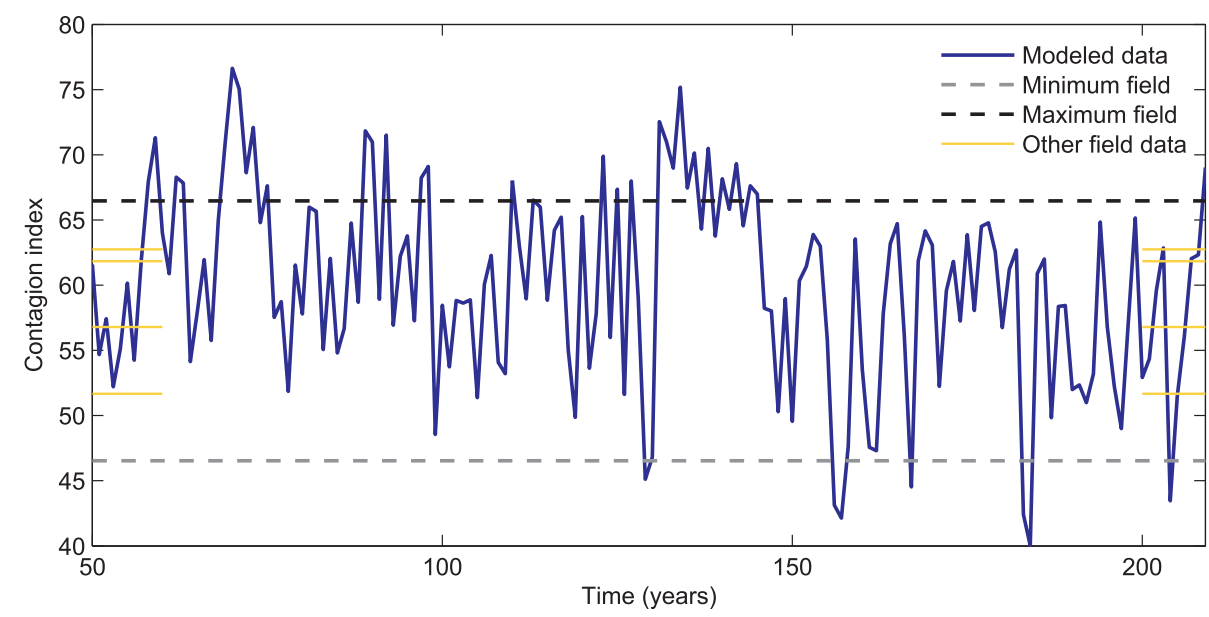

Fig. 2. Contagion Index of modeled data compared to field data. The minimum contagion index calculated with field data is indicated by the grey dashed line, the maximum by the black dashed line and the other field data by the orange lines on the side. (For interpretation of the references to colour in this figure legend, the reader is referred to the web version of this article.) previous version of the model. This results in a more dynamic and realistic system because changes in hydro-morphodynamics directly affect vegetation processes and vice versa. Furthermore we used real discharges from the Allier rather than several general discharge events as in van Oorschot et al. (2016), requiring that the mortality thresholds of Salicaceae species were re-calibrated to approximate a total Salicaceae cover of $15 \%$ after 150 years and an age distribution with a pioneer, bush and forest ratio of 0.2:0.5:0.3 (as in Geerling et al., 2006; van Oorschot et al., 2016). Fig. 1 shows a comparison of patterns in vegetation and morphology between model results and observations from aerial photos. Results show that modelled vegetation cover and vegetation age distribution and morphologic patterns are comparable to field observations. Additionally, we calculated the Contagion Index to quantify and compare the vegetation patterns between the model and the field (Fig. 2). The Contagion Index is a measure for landscape diversity (Li and Reynolds, 1993) and quantifies the composition and the configuration of the landscape on the basis of the number of patch types, their relative proportions and their spatial patterns. To create a fair comparison, the field data were structured such that the typology, dimensions and resolution were comparable to the model output. With ArcMap 10.4.1, the classified raster maps from 1954, 1960, 1967, 1978, 1985 and 2000 from Geerling et al. (2006) were cut into comparable dimensions as the modeled area ( $1000 \times 3600$ meter). Subsequently, the resolution was adjusted from $10 \times 10$ meter to $25 \times 25$ meter with the resample function based on nearest neighbour. Then, the vegetation classes were reclassified into closed forest, open forest, closed bush, open bush, pioneer and a rest class containing water, bare substrate and vegetation types that were not included in the model. The model results were also classified into similar vegetation classes based on vegetation age and fraction. Pioneers are considered as 1-year-old plants, shrubs are considered as plants between 2 and 10 years old and forest are plants older than 10 years. If vegetation occurred in a fraction higher than 0.6 , the vegetation type was considered 'closed', otherwise 'open' in accordance with Geerling et al. (2006). The Contagion Indices were 
calculated with the Fragstats software (McGarigal and Marks, 1995). The Contagion Index of the modelled landscape falls within a similar range as the contagion index calculated with field data (Fig. 2). We take this as evidence that the patterns produced by the model are similar enough to those observed in nature.

Salicaceae species have an inter-annual growth cycle that was represented in the model as a logarithmic growth curve, which means that their shoot and root size increased every year. They contained different life stages that differed in number of stems per $\mathrm{m}^{2}$ and sensitivity for hydro-morphodynamic pressures (van Oorschot et al., 2016). In the model, species growth rates were assumed not to be affected by resource limitation or competition, e.g. shadowing and moisture availability. Groundwater access was not modelled explicitly, but was indirectly calibrated by setting higher desiccation thresholds for mortality, especially for older vegetation. We assumed that these older vegetation types had better access to groundwater during times of low flow, because of their increased rooting depth.

Vegetation interacts with hydro-morphodynamic processes through its hydraulic resistance. This depends on the height of the vegetation, determining whether water flows only through or also over the vegetation, and on vegetation density, which is expressed by the stem diameter, the number of stems per unit area, and the fraction with which vegetation occupies the cell (Baptist et al., 2007). Hydraulic resistance caused by vegetation was calculated in each grid cell with the Baptist et al. (2007) relation. Sediment stabilization by roots was not explicitly considered in the model. The current version of Delft3D uses a relatively simple bank erosion module that is not able to simulate detailed lateral bank erosion with processes like undercutting and bank failure of steep banks. Bank erosion takes place when a cell is incised and subsequently causes the dry neighbour cells to decrease by $50 \%$ of the incised amount. Because vegetation reduces flow velocity, the amount of bed erosion within vegetated patches is low.

During a simulation, plants die through flooding, desiccation, uprooting, scour and burial depending on their sensitivity to these pressures. For Salicaceae species, this sensitivity was life-stage dependent, with younger vegetation being more sensitive to morphodynamic pressures. Plants that remain unaffected by morphodynamic processes die due to senescence when a pre-defined maximum age was reached, i.e. 60 years for Salix and 150 years for Populus (Braatne et al., 1996; Peters, 2002). Flooding, desiccation and uprooting mortality is calculated with the dose-effect relation described in van Oorschot et al. (2016). The values of the thresholds and slopes in the dose-effect relations for Salicaceae species are presented in Table 1.

\subsection{Setup of scenarios}

Two scenarios representing contrasting dam operating regimes were generated: one with only a stabilized flow regime and one with a reversed flow seasonality (Fig. 3a). Two contrasting climate change scenarios were generated: one with a general drying trend (Van Vliet et al., 2013) and one with increasing extreme events in low and high flows, based on changing precipitation regimes (Dankers and Feyen, 2008) (Fig. 3b). Also, four combination scenarios with climate change and dam operation were generated (Table 2).

In all these scenarios, only the upstream discharge boundary was adjusted, while all other conditions, including the sediment concentrations and vegetation settings were kept the same. This amounts to the assumption that the dams were constructed so far upstream that the river was able to pick up sufficient sediment downstream of the dam so that the sediment regime of the modelled section remained unaltered. The sediment influx at the upstream boundary was kept in equilibrium with the transport capacity, meaning that no net erosion was enforced such as would occur immediately downstream of a dam. Consequently, the sediment concentration at the upstream boundary was similar to that at the downstream boundary. This prevented steep sediment transport gradients leading to strong local erosion that would not occur in river reaches further downstream of the dam. We are aware that reservoir dams trap sediment, which affects downstream sediment transport. However, the largest effects occur immediately downstream of the dam and the sediment flux further downstream is hardly affected (Ribberink and Van der Sande, 2000; Middelkoop et al., 2015). In contrast, the changes in water flow regime have a direct impact over considerably longer distances.

We used daily discharges from the Allier measured near the town of Moulins between 1968 and 1992 as the reference for the scenario runs. To generate discharge series for the scenario period until the final projection year 2100 for the scenarios, we randomly sampled years from the reference period, hence preserving discharge variations within the year. For optimal comparison, all altered flow scenarios were generated with this same time series. After generation of the flow alteration scenarios, the discharges were monthly averaged before the start of the simulations.

\subsubsection{Dam scenarios}

We created a discharge scenario with a dam operating regime of a reservoir that functions as a buffer to attenuate peak flows for flood protection in winter and that stores water to increase the minimal flow in summer for water consumption downstream. The resulting discharge regime maintains a similar, but damped, seasonal variation when compared to the natural flow (Fig. 3a). In this scenario, the data is divided in a wet period from December until May and a dry period from June until November, unless the discharge in the wet period is below the given threshold of $90 \mathrm{~m}^{3} / \mathrm{s}$ or if the reservoir volume is too low, then the period is considered dry. At the same time, the reservoir volume is maintained within pre-set minimum and maximum volumes by decreasing the minimum discharge released $\left(Q_{\text {low }}\right)$ when there is too little water. When there is too much water in the reservoir, this excess amount of water is released, causing peak flows. The released discharge is smoothed over 10 antecedent days, to represent responsive release to preceding inflow and attenuation of minor discharge fluctuations towards the downstream river reach. The dam operating scenario with a stabilized flow regime and maintained seasonality of the flow is referred to as 'stable dam scenario'.

The scenario with reversed flow regime represents a more extreme flow alteration with totally reversed seasonality aiming at water provision for downstream areas during the dry season (Richter and Thomas, 2007). During the season with high flow, water is stored in the reservoir, resulting in a low released water flow. Conversely, during the dry season a large water flow is released from the reservoir that is then gradually emptied. A second effect of this scenario is that it totally

Table 1

Mortality parameters for Salicaceae seedlings (1 yr old), saplings (2-10 yrs) and forest (older than $10 \mathrm{yrs}$ ) in all scenarios.

\begin{tabular}{|c|c|c|c|c|c|c|c|}
\hline Flooding threshold & $d$ & 40 & 35 & 230 & 220 & 310 & 290 \\
\hline Flooding slope & - & 0.75 & 0.75 & 0.8 & 0.8 & 0.5 & 0.5 \\
\hline Desiccation slope & - & 0.75 & 0.75 & 0.3 & 0.3 & 1 & 1 \\
\hline Uprooting threshold & $\mathrm{m} / \mathrm{s}$ & 0.55 & 0.55 & 3.5 & 3.5 & 12.0 & 12.0 \\
\hline Uprooting slope & - & 0.75 & 0.75 & 0.75 & 0.75 & 0.3 & 0.3 \\
\hline
\end{tabular}




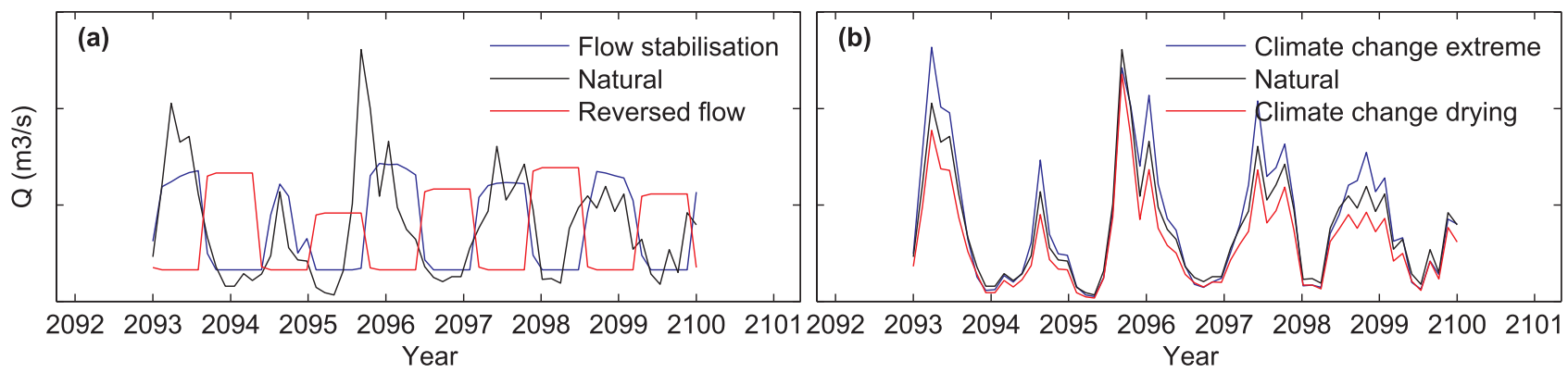

Fig. 3. Generated hydrographs for the last 6 years of scenarios with dams (a) and climate change (b) compared to the natural flow regime.

Table 2

Overview of single-pressure model scenarios and combined-pressure scenarios.

\begin{tabular}{cll}
\hline $\begin{array}{l}\text { Reference with natural } \\
\text { flow regime without } \\
\text { pressures }\end{array}$ & Dam stable & Dam reversed \\
\hline $\begin{array}{c}\text { Climate change drying } \\
\text { trend(CCdry) }\end{array}$ & $\begin{array}{l}\text { Dam stable + climate } \\
\text { change drying trend } \\
\text { Dam stable + climate } \\
\text { events (CCextreme) }\end{array}$ & $\begin{array}{l}\text { Dam reversed + climate } \\
\text { change drying trend } \\
\text { Dam reversed + climate } \\
\text { change extreme events }\end{array}$ \\
\hline
\end{tabular}

removes peak flows that occur during the wet season when the reservoir fills up, and thus avoids flooding. To construct the hydrograph for this scenario a similar division was made in wet and dry periods as in the stable dam scenario. The original wet period is given a constant minimal discharge of $65 \mathrm{~m}^{3} / \mathrm{s}$ and the discharge in the original dry period depends on previous conditions and the available water (Fig. 3a and Table 3). This dam operating scenario with the seasonally reversed flow regime will henceforth be called 'reversed dam scenario'.

In both dam operating scenarios, the total amount of water annually released to the downstream river is comparable to the reference scenario; the dam only redistributes the amount of discharge over the year.

\subsubsection{Climate change scenarios}

The climate change scenario with a general drying trend is based on results of Van Vliet et al. (2013) for the Loire river. Here, reductions of $23 \%, 53 \%$ and $7 \%$ were obtained for normal flows, low flows and high flows respectively. These percentages are averages of six bias-corrected general circulation models for both SRES A2 and B1 emission scenarios. Low flows are expressed as flows lower than 10th percentile, high flows as discharges higher than the 95th percentile and the normal discharges include all discharges between the low and high flows. The reductions were applied to the time series of observed Allier discharges as percentage changes of the low-, high- and normal discharges; gradual changes from the present to the projection year 2100 were obtained by straightforward interpolating the changes in equal steps per year (Fig. 3b). This scenario results in a decrease in discharge over time.

The climate change scenario with extreme events is derived from a region climate modelling study by Dankers and Feyen (2008), based on the high-end IPCC SRES-A2 scenario (IPCC, 2000). This study provided changes in average seasonal precipitation. Because the Allier is mainly a rain-fed river, we adopted the changes in precipitation for estimating changes in river discharge. Accordingly, this scenario involves a flow increase by $30 \%$ in winter (DJF) and by $15 \%$ in spring (MAM), and a decrease in river flow by $30 \%$ in summer (JJA) and by $7.5 \%$ in autumn (SON). The percentages of change were applied to the reference time series 1992-2100 in the same manner as in the other climate change scenario, now taking into account the different seasons (Fig. 3b). This scenario results in an increase in discharge over time.

\subsection{Habitat suitability models}

The spatial analysis tool HABITAT (Haasnoot and van de Wolfshaar, 2009) was used to establish habitat suitability models for species and species groups representative for the complete lateral fluvial gradient from main channel to the highest elevations on the floodplains: fish spawning and egg incubation, macrophytes, helophytes, riparian grassland and hardwood forest. HABITAT uses dose-effect relations of species based on a set of critical habitat requirements as input. These effect relations indicate the boundaries of environmental conditions for the expected presence of species. HABITAT translates each environmental parameter map to a habitat suitability index map on a scale

Table 3

Equations used to derive discharges for both dam operating regimes from the natural discharge time series. The annual discharge sum is comparable to the natural discharge time series.

\begin{tabular}{|c|c|c|}
\hline \multicolumn{3}{|l|}{ Reversed flow regime } \\
\hline \multicolumn{3}{|l|}{$\begin{array}{l}Q_{\text {wet }_{\mathrm{t}}}=Q_{\text {low }} \\
Q_{\text {dryt }_{\mathrm{t}}}=\overline{Q_{\text {wet }}}-Q_{\text {low }}+\overline{Q_{\text {dry }}}\end{array}$} \\
\hline \multicolumn{3}{|l|}{ Stable flow regime } \\
\hline $\begin{array}{l}\text { if }\left(\mathrm{RV}_{\mathrm{t}-1}<\mathrm{RV}_{\min }\right) \mathrm{Q}_{\mathrm{dry}}=\min \left(\mathrm{Q}_{\mathrm{t}}, \mathrm{Q}_{\text {low }}\right) \\
\text { if }\left(\mathrm{RV}_{\mathrm{t}-1}<\mathrm{RV}_{\text {min }}\right) \mathrm{Q}_{\mathrm{wett}}=\mathrm{Q}_{\text {low }}\end{array}$ & $\begin{array}{l}\text { elseif }\left(\mathrm{RV}_{\mathrm{t}-1}>\mathrm{RV}_{\max }\right) \mathrm{Q}_{\mathrm{dry}_{\mathrm{t}}}=\max \left(\mathrm{Q}_{\mathrm{t}}, \mathrm{Q}_{\text {low }}\right) \\
\text { else } \mathrm{Q}_{\text {wet }_{\mathrm{t}}}=Q_{\text {high }} \times 0.9 \times 1-\left(\frac{R V_{\text {total }}-R V_{\mathrm{t}-1}}{R V_{\text {total }}}\right)\end{array}$ & else $\mathrm{Q}_{\mathrm{dry}_{\mathrm{t}}}=\mathrm{Q}_{\text {low }}$ \\
\hline Parameter & Value & Description \\
\hline$Q_{\mathrm{dry}_{\mathrm{t}}}$ & New discharge in original dry period & Variable \\
\hline$Q_{\text {wett }}$ & New discharge in original wet period & Variable \\
\hline$Q_{\text {low }}$ & Minimum discharge during new dry period & 65 \\
\hline$Q_{\text {high }}$ & Minimum discharge during wet season & 160 \\
\hline$R V_{\min }$ & Minimum reservoir volume & 5000 \\
\hline$R V_{\max }$ & Maximum reservoir volume & 45.000 \\
\hline$R V_{\text {total }}$ & Total reservoir volume & 50.000 \\
\hline
\end{tabular}


from zero to one. Since the limiting environmental parameter determines the eventual suitability, the minimum of all environmental parameters per grid cell was used as the final habitat suitability index.

We used habitat requirements for Alopecurion pratensis as the general type for riparian grassland occurring on the lower parts of the floodplain that can withstand periodic flooding (van der Perk, 1996). Reed (Phragmites australis) was chosen as the representative for helophytes. For macrophytes we use a more general suitability curve comprised of environmental boundaries for a range of macrophyte species (Geest and Teurlincx, 2010). We considered two different fish species: spawning and egg incubation of the Atlantic salmon (Salmo salar), and spawning of the pike (Esox lucius). These species were chosen because they represent two functional groups: rheophilic, i.e. preferring flowing water (salmon) and limnophilic, i.e. preferring stagnant or slow moving water (pike). The habitat suitability analysis was done as post-processing; interactions among different species were not considered. For each species, relevant statistics of habitat characteristics were calculated for each simulation year from the bio-geomorphological model output, and used as input parameters for the habitat suitability models. These parameters combined with dose-effect relations were used to calculate the habitat suitability of the selected species and species groups for each simulation year (Table 4).

For plant species occurring in less disturbed environments, conditions have to be stable for a period of time before a viable population can develop. Other species, like pike, can overcome several years without good recruitment due to poor spawning conditions and still maintain a viable population. Therefore, we also calculate a population response as opposed to absolute habitat suitability, which takes this stability requirement into account. The antecedent conditions for macrophytes and helophytes have to be suitable for 5 consecutive years (Geest and Teurlincx, 2010). This is calculated by weight-averaging of the habitat suitability per grid cell over the previous 5 years, where higher weight is added to years closer to the year under consideration. This is done linearly with the numbers of years under consideration, i.e. when 5 antecedent years are considered the year under consideration counts 5 times, the year before that 4 times, and so on.

The effect of habitat suitability on pike population is determined by its spawning age and maximum age. On average, the pike reaches spawning age after 4 years and its maximum age is 12 years (De Laak and Van Emmerik, 2006). Assuming that the pike reaches its maximum age, it requires at least 1 year with suitable conditions every 8 years to reproduce. Therefore, the population response for pike in the year under consideration was calculated by taking the maximum habitat suitability over 8 antecedent years. This means a simplification in that we ignore population size and biomass. For grassland, we assumed that conditions have to be within the suitability boundaries for a minimum of 5 consecutive years, for hardwood shrubs 10 years and for hardwood forest 30 years (van der Perk, 1996). We did not account for connectivity between landscape units, meaning that we assume this to be sufficient for fish species to complete their life cycle by migrating between floodplain and main channel.

\subsection{Data analysis}

All statistics used for analysing model results were calculated from year 1992 (model year 100) onwards, and excluded a 500-meter zone from the upstream and downstream boundaries to minimize the boundary effects. All time series were smoothed by moving average over 10 years to filter out effects of individual floods. Bed level data was detrended and normalized as described in van Oorschot et al. (2016).

\subsubsection{Morphodynamic parameters}

Peak discharges were calculated as the 95th percentile of all daily discharges per year, and values were subsequently plotted as the median per selected time interval (1992-2016; 2017-2041; 2042-2066; 2067-2100). The spread in the peak discharge was represented by the 5th and 95th percentile of all peak discharges per time interval. Total morphodynamic activity per year was calculated as the median absolute difference between the bed level at the beginning of each year and the end of each year, per selected time interval. Sinuosity was calculated as described in van Oorschot et al. (2016). Channel width-depth ratios, indicative of channel shape and stability, were calculated by determining the width and maximum depth of the main channel for each cross section and each ecological time step. Here, the main channel was determined from water level and bed level, where we assumed that the widest channel in each cross-section was the main channel. Subsequently the median of the width-depth ratios over all cross sections and ecological time steps was calculated to obtain data per year. The wetted area was defined as the total area with a water level larger than zero for each ecological time step. Subsequently the median was calculated over all ecological time steps to obtain values per year.

\subsubsection{Vegetation parameters}

The vegetated area was calculated by summarizing all fractions with which vegetation occupied the grid-cells per age class of vegetation (1 year old seedlings, 2-10 year old saplings and forest older than 10 years) in the last ecological time step of the year. The vegetated belt (i.e., the height zone where vegetation occurs) was calculated by obtaining the absolute difference between the 25th percentile and the 75th percentile of the bed level of vegetated cells. This value indicates the width of the vegetated bed level elevation range, but for readability this will henceforth be called 'vegetated belt'. Suitable habitat area per species per year was calculated as the percentage of grid cells where habitat suitability value is higher than 0.5 . This was done for the habitat suitability maps as direct output from HABITAT and for the modified suitability maps where we took population requirements of stability over a certain period into account, explained in Section 2.3.

\section{Results}

\subsection{Morphodynamics}

The model runs for single-pressure scenarios result in different river channel patterns, floodplain elevation and vegetation age and distribution, but all yield a single thread, meandering channel (Fig. 4). All scenarios except the extreme climate change scenario result in a lower morphodynamic activity than the natural flow regime (Fig. 5a). For the dam scenarios this is caused by the immediate decrease in median annual peak discharge that accounts for a large proportion of the total sediment transport (Fig. 5b). For the scenario with the drying trend, reduced morphodynamic activity is caused by the gradual reduction of discharge, whereas the extreme events scenario has discharge increasing over time. Generally, a combination of dams and drying by climate change leads to a further decreasing trend of morphodynamic activity, while extreme events increase morphodynamic activity over time, although not in a linear trend over the time periods (Fig. 5a). However, there are some remarkable trend 'breakers' with high morphodynamic activity in the second interval for the dry scenario and the last interval for the reversed dam scenario. This is most likely caused by large discharge peaks during these intervals (Fig. 5b). In the dry scenario this initiates the cut-off of two meander bends occurring between 2029 and 2042, visible in Fig. 4b in the year 2050. Furthermore, a stable dam combined with extreme events surprisingly has the lowest morphodynamic activity in the last interval, although the peak discharges are not lower. The results from this scenario show a continuously increasing vegetation cover (Fig. 6), which could be the cause of the drop in morphodynamic activity.

All scenario results show a large variation in width-depth ratio over time, which is due to decadal trends in discharge rather than individual floods. More importantly, most scenarios result in smaller width-depth ratios than the reference scenario (Fig. 7c). The gradual effect of 
Table 4

Dose-effect relations for habitat suitability for Atlantic salmon, pike, macrophytes, helophytes, hardwood forest and grassland.

\begin{tabular}{|c|c|c|c|c|c|}
\hline Parameter & Time frame (\# month in year) & Value*1 & Unit & Rule type ${ }^{* 2}$ & Reference \\
\hline & Pike spawning & & & & \\
\hline Mean flow velocity & $2-4$ & {$[0,0] ;[0.05,1] ;[0.1,1] ;[0.2,0.5] ;[0.3,0] ;[5,0]$} & $\mathrm{m} / \mathrm{s}$ & $\mathrm{L}$ & Inskip (1982) \\
\hline Max flow velocity & $2-4$ & $\leqslant 0.3$ & $\mathrm{~m} / \mathrm{s}$ & B & Inskip (1982) \\
\hline Min flow velocity & $2-4$ & $>0$ & $\mathrm{~m} / \mathrm{s}$ & $\mathrm{B}$ & Excludes areas without flow \\
\hline Mean water depth & $2-4$ & {$[0,0] ;[0.1,0] ;[0.3,1] ;[0.6,1] ;[1.4,0] ;[, 0]$} & $m$ & $\mathrm{~L}$ & Inskip (1982) \\
\hline Max water depth & $2-4$ & $<2.0$ & $m$ & $\mathrm{~B}$ & De Laak and Van Emmerik (2006) \\
\hline \multirow[t]{2}{*}{ Min water depth } & $2-4$ & $\geqslant 0.10$ & $m$ & B & De Laak and Van Emmerik (2006) \\
\hline & Salmon spawning & & & & \\
\hline Mean flow velocity & $11-12$ & {$[0,0] ;[0.08,0] ;[0.13,1][0.45,1] ;[1,0] ;[, 0]$} & $\mathrm{m} / \mathrm{s}$ & $\mathrm{L}$ & De laak (2007) \\
\hline Max flow velocity & $11-12$ & $\leqslant 1.0$ & $\mathrm{~m} / \mathrm{s}$ & $\mathrm{B}$ & De laak (2007) \\
\hline Min flow velocity & $11-12$ & $>0.1$ & $\mathrm{~m} / \mathrm{s}$ & $\mathrm{B}$ & Excludes areas without flow \\
\hline Mean water depth & $11-12$ & {$[0,0] ;[0.15,1] ;[0.35,1] ;[0.7,0]$} & $m$ & $\mathrm{~L}$ & De laak (2007) \\
\hline Max water depth & $11-12$ & $<0.7$ & $m$ & $\mathrm{~B}$ & De laak (2007) \\
\hline \multirow[t]{2}{*}{ Min water depth } & $11-12$ & $\geqslant 0.15$ & $m$ & B & De laak (2007) \\
\hline & Salmon egg incubation & & & & \\
\hline Mean flow velocity & $1-4$ & {$[0,0] ;[0.08,0] ;[0.13,1][0.45,1] ;[1.5,0] ;[, 0]$} & $\mathrm{m} / \mathrm{s}$ & $\mathrm{L}$ & De laak (2007) \\
\hline Max flow velocity & $1-4$ & $\leqslant 1.5$ & $\mathrm{~m} / \mathrm{s}$ & B & De laak (2007) \\
\hline \multirow[t]{2}{*}{ Min flow velocity } & $1-4$ & $>0.1$ & $\mathrm{~m} / \mathrm{s}$ & B & De laak (2007) \\
\hline & Macrophytes & & & & \\
\hline Mean water depth & 5 & {$[0,0] ;[0.5,1] ;[1.5,1] ;[1.9,0] ;[, 0]$} & $m$ & $\mathrm{~L}$ & Geest and Teurlincx (2010) \\
\hline Min water depth & $5-7$ & $>0.1$ & $m$ & B & Geest and Teurlincx (2010) \\
\hline Max flow velocity & $5-8$ & $\leqslant 0.35$ & $\mathrm{~m} / \mathrm{s}$ & B & low dynamic areas defined in Maas (1998) \\
\hline \multirow[t]{2}{*}{ Morphodynamic activity } & $1-12$ & $\leqslant 10$ & $\mathrm{~cm}$ & $\mathrm{~B}$ & Disturbance assumption \\
\hline & Helophytes & & & & \\
\hline Mean water depth & $5-10$ & {$[0,0] ;[0.1,0] ;[0.5,1] ;[1.5,1] ;[2.1,0] ;[, 0]$} & $m$ & $\mathrm{~L}$ & Dikker (1974) \\
\hline Max Water depth & $5-10$ & $<$ shoot height ${ }^{* 4}$ & $m$ & $\mathrm{~L}$ & Pers. Comm. Dr. G. van Geest \\
\hline Max flow velocity & $5-8$ & $\leqslant 0.35$ & $\mathrm{~m} / \mathrm{s}$ & B & low dynamic areas defined in Maas (1998) \\
\hline \multirow[t]{2}{*}{ Morphodynamic activity } & $1-12$ & $\leqslant 10$ & $\mathrm{~cm}$ & B & Disturbance assumption \\
\hline & Hardwood forest & & & & \\
\hline \multirow[t]{2}{*}{ Inundation time } & $1-12$ & $\leqslant 20$ & days $^{* 4}$ & $\mathrm{~L}$ & Klijn et al. (2002) \\
\hline & Grassland & & & & \\
\hline Inundation time & $1-12$ & $50-150$ & days & $\mathrm{L}$ & Maas (1998) \\
\hline
\end{tabular}

${ }^{1}$ The values indicate a HSI of 1.0 , other values represent a HSI of 0 .

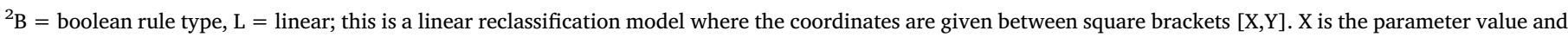
$\mathrm{Y}$ is the HSI value.

${ }^{3}$ Link to ecological database (in Dutch): https://publicwiki.deltares.nl/display/HBTHOME/04 + Fish

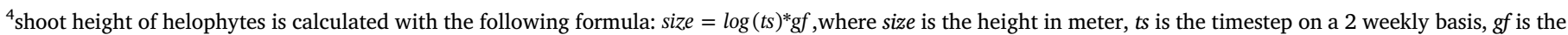
growth factor (set to 2).

${ }^{5}$ inundation time is expresses as number of subsequent days of flooding.

climate change in the combined dam scenarios is reflected in the trends in width-depth ratios (Fig. 7d). In general, climate change occurring in situations with dams results in a further deviation of the width-depth ratio from the reference scenario. Only climatic drying as a single pressure or in combination with a reversed flow regime causes the width-depth ratio to increase for the majority of the final 50 years of the run, which can be attributed to the total decreasing discharge.

The scenarios with dams and climate-induced increased extreme events result in incision of the river by initially creating deeper and narrower channels. This may have multiple causes, such as a changed flood regime and vegetation density changes that concentrate flow more into channels. The width-depth ratio is also influenced by chute cut-offs, that create a steeper gradient, lower water levels and subsequently a lower width-depth ratio. Chute cut-offs are visible as large drops in sinuosity, indicative for large landscape rearrangements
(Fig. 7a and b). The width-depth ratio in the reversed dam scenario is increasing over time, indicating that the river is developing towards wider and shallower channels. For the stable dam scenario, the widthdepth ratio remains relatively stable, indicating the channel cross sectional shape is more in a dynamic equilibrium state.

Clearly, due to the multiple large-scale processes there is no simple straightforward relation between discharge alteration and morphodynamic response due to the interaction of local morphodynamics, major events and related vegetation response acting at different response and adjustment timescales.

\subsection{Vegetation cover and age distribution}

Both dam operating regimes have large and acute effects on total riparian area and age distribution compared to the natural flow regime 


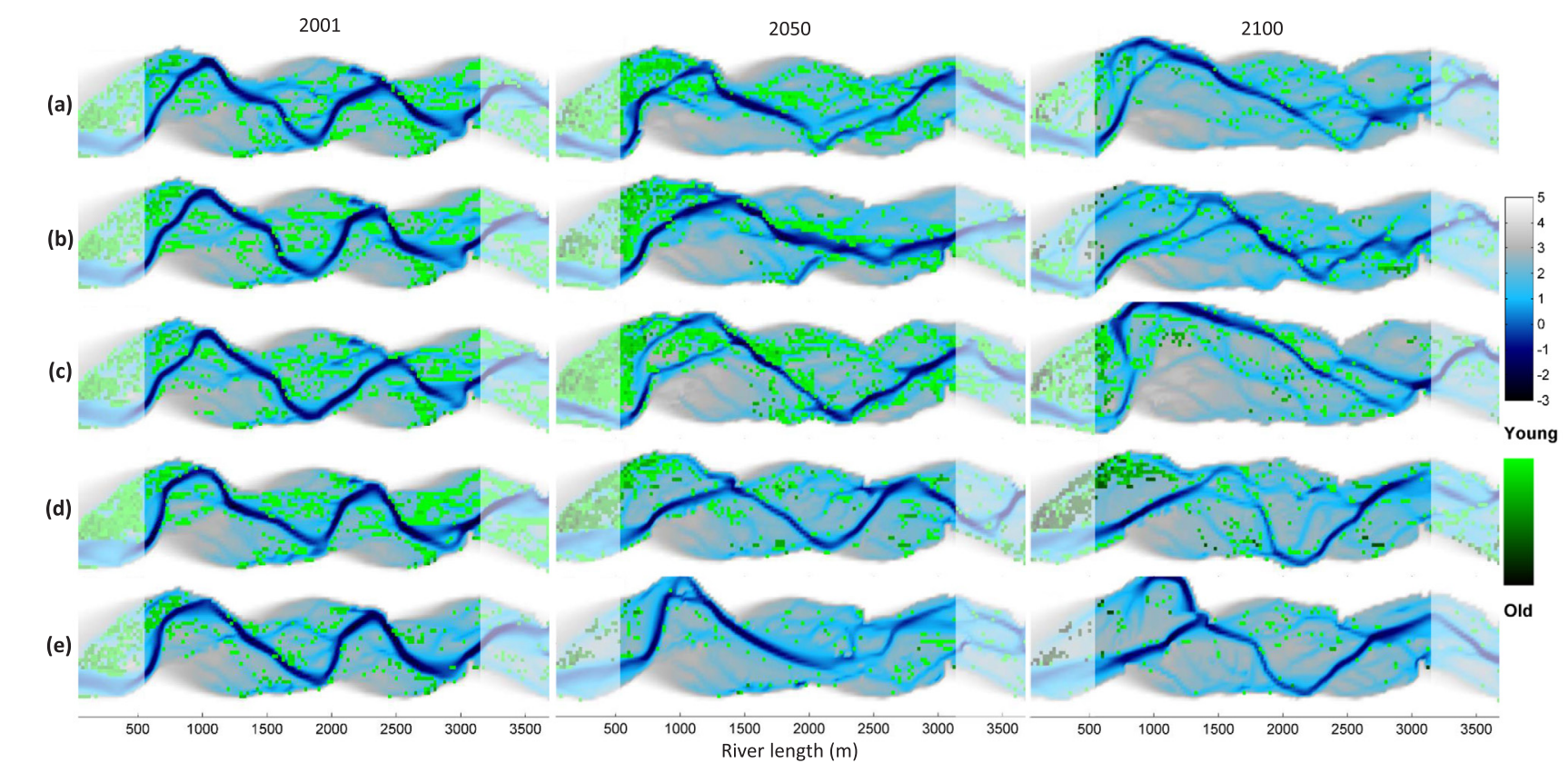

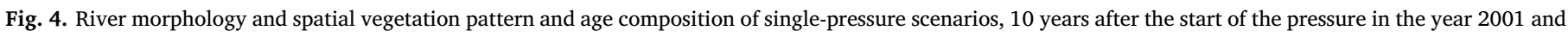

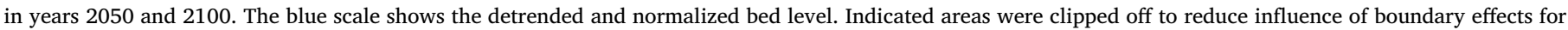

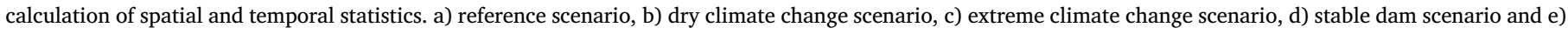
reversed dam scenario.

(Figs. 4 and 6). Under the stable dam flow regime, the total vegetated area initially declines for approximately 10 years before it rapidly increases again and leads to aging. Due to flow stabilisation, year-to-year variability in seedling establishment decreases, leading to a smaller variation in settling between different years and aging of vegetation. A reversed flow regime strongly reduces seedling establishment, followed by a massive total reduction of vegetated area when older trees die from senescence, while no new riparian vegetation establishes. Not surprisingly, total vegetated area under both climate change scenarios initially does not deviate much from the reference scenario (Figs. 4 and 6). Nevertheless, changes become apparent towards the end of the simulated periods, when the climatic effects fully manifest in river discharge (Fig. 6). The area for seedlings is declining due to decreasing river discharge under a drier climate, while under a climate scenario with increasing extremes a wider area becomes available for settling, leading to increased seedling recruitment. For the scenarios combining dams with climate change, we find that drying initially leads to increased

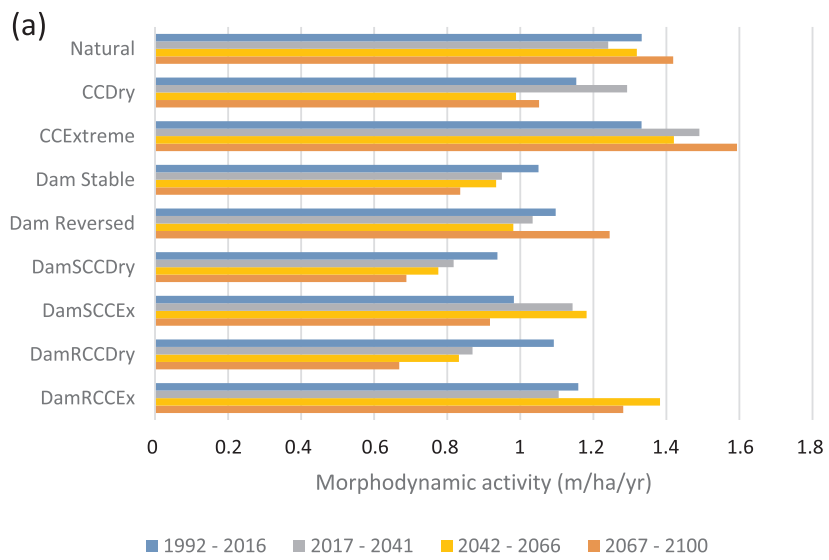

aging and reduced seedling recruitment. However, extreme events can restore seedling recruitment, leading to a continuously increasing vegetation cover in the stable flow regime and increased year-to-year variability of seedlings in both dam operating regimes.

\subsection{Vegetation colonisation and survival}

In both dam scenarios the location for vegetation settlement shifts towards higher elevations on the floodplain (Figs. 8c). Most survival under a reversed flow regime occurs on higher bed level elevations, which is clearly controlled by the discharges during the winter and summer (Fig. 8e and g). Under a stable flow regime, the most suitable elevation for survival deviates less from the reference scenario. Under decreasing discharge due to climatic drying, the location for vegetation settlement is shifting towards lower elevations on the floodplain, while extremes cause an opposite trend (Figs. 8c). This can be linked to the discharges during the seed dispersal season (Fig. 8a). The vegetated belt

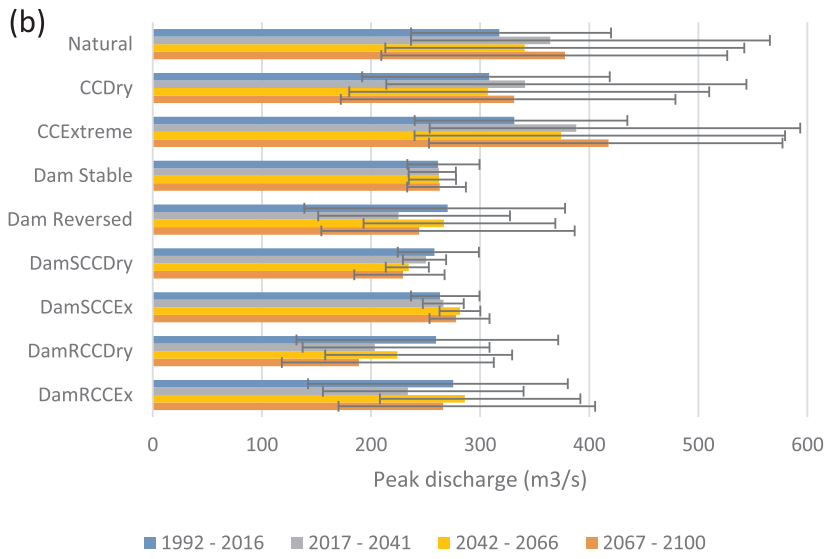

Fig. 5. a) Morphodynamic activity expressed as the sum of absolute bed level changes. b) Peak discharge magnitude, calculated as the median of the 95th percentile of annual discharges per time interval indicated in the legend. Error bars represent the 5th and 95th percentile ranges of the annual peak discharges within time intervals. 

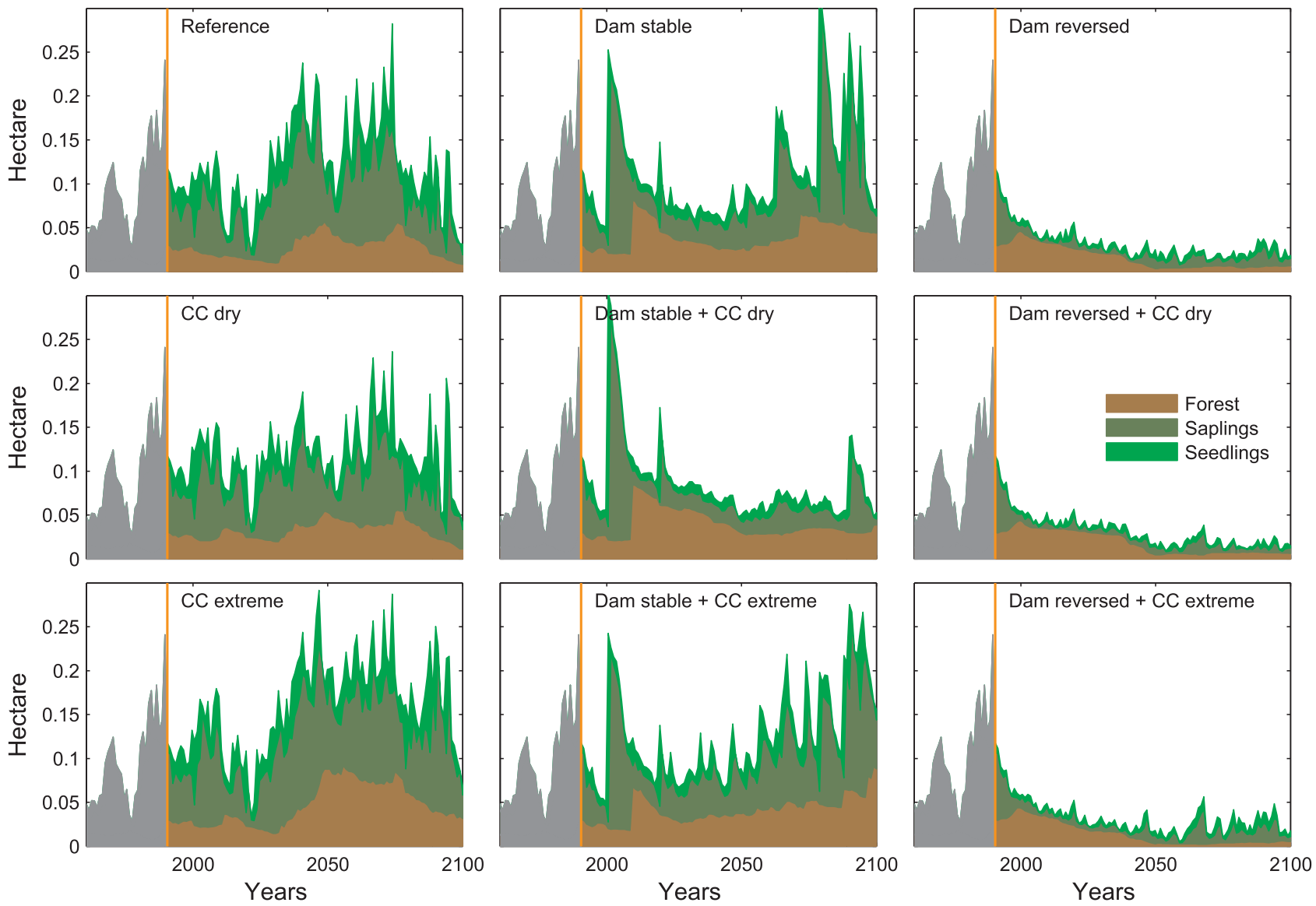

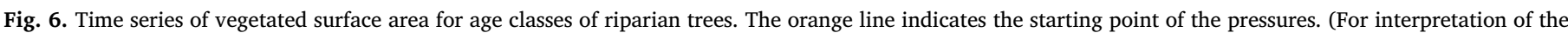
references to colour in this figure legend, the reader is referred to the web version of this article.)

is a measure of morphodynamic confinement of vegetation on the floodplain. A larger vegetated belt indicates that more bed level elevations are covered with vegetation. This is usually closely linked to the wetted area of the floodplain, indicative of the area that is under direct influence of the river. Both dam scenarios initially result in a large decrease in the vegetated belt, whereas the vegetated belt under a stable flow regime starts to recover after about 25 years. Under the reversed flow regime, the decrease is very rapid, and there is no clear
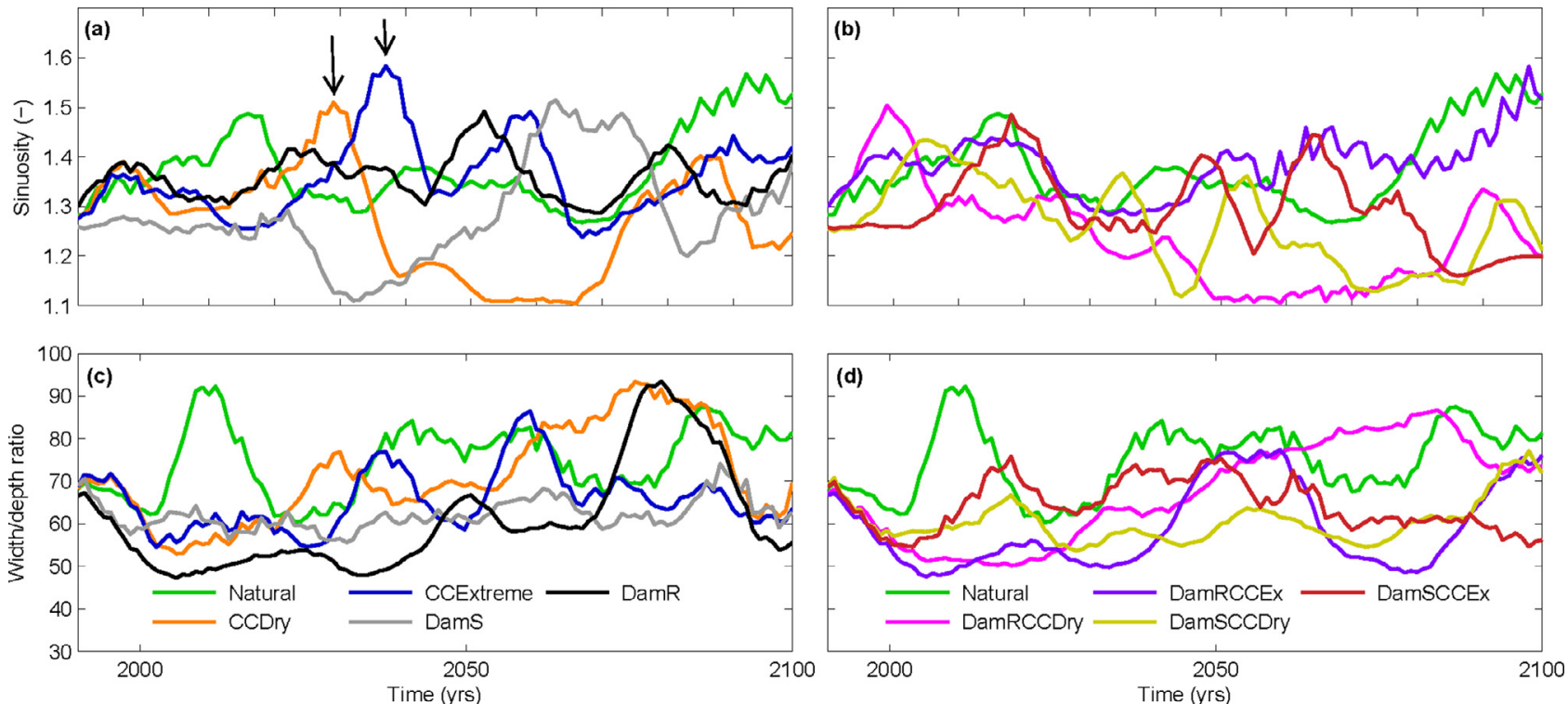

Fig. 7. Time series of morphodynamic characteristics. Sinuosity of single-pressure scenarios (a) and multiple-pressure scenarios (b). The arrows indicate examples of large chute cut-offs that rearrange the floodplain. Channel incision and focus of flow on the fluvial plain represented by channel width-depth ratios calculated as the median along the model grid for all ecological time steps in a year for single-pressure scenarios (c) and multiple pressure scenarios (d) (see detailed description in Section 2.4.1). 

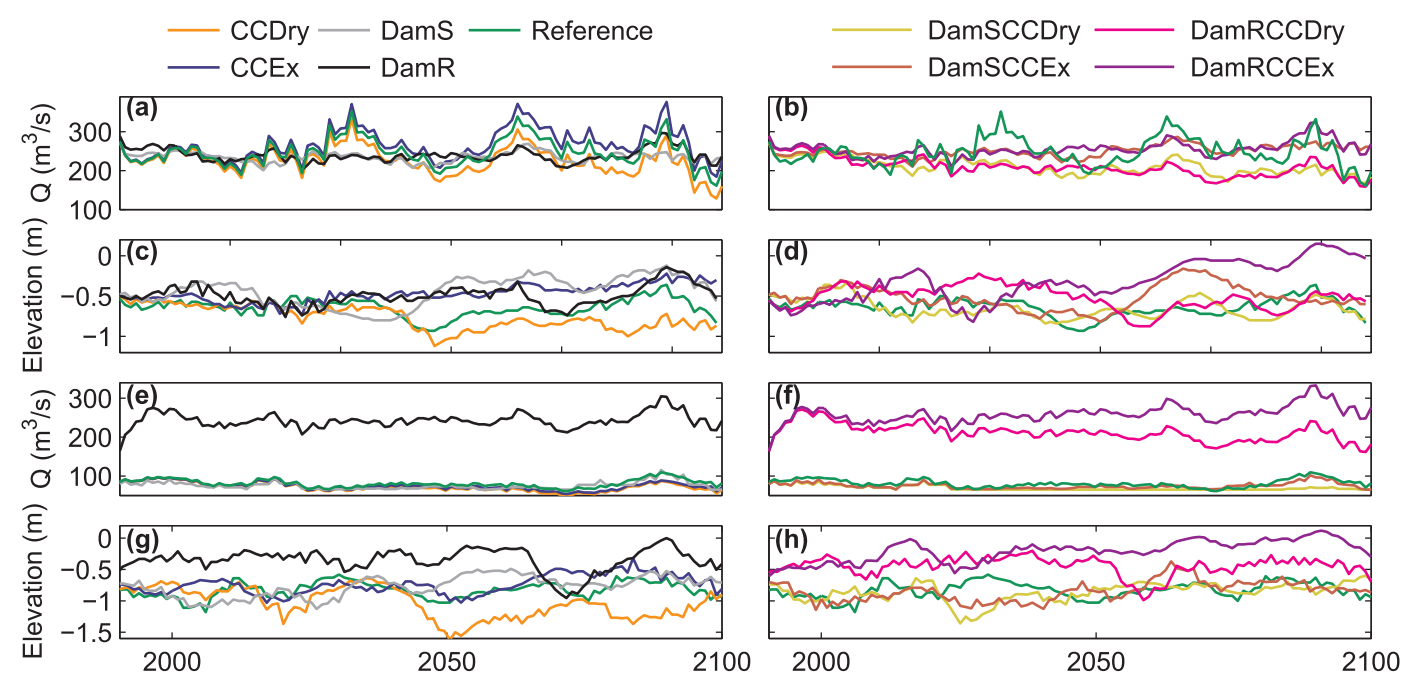

Fig. 8. Conditions in which most riparian vegetation colonizes and survives. Maximum discharge during the seed dispersal season for the single-pressure scenarios (a) and combined-pressure scenarios (b). Bed level elevation where most vegetation colonizes for the single-pressure scenarios (c) and combined-pressure scenarios (d). Median discharge from moment of colonization until the end of the year for the single-pressure scenarios (e) and the combined-pressure scenarios (f). Bed level elevation where most vegetation survives for the single-pressure scenarios $(\mathrm{g})$ and the combined-pressure scenarios $(\mathrm{h})$.
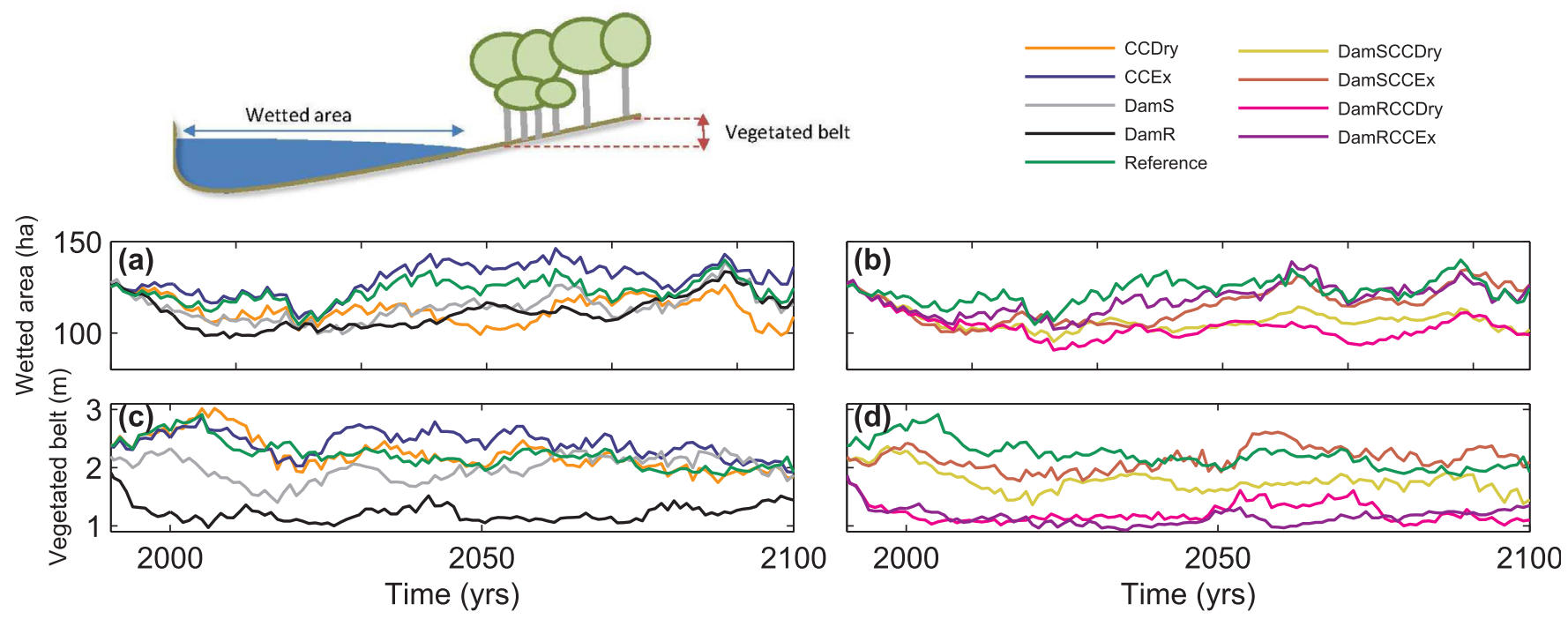

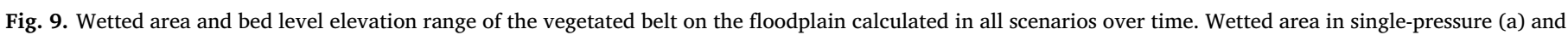
combined-pressure scenarios (b). Vegetated belt in single-pressure (c) and combined-pressure scenarios (d).

recovery over time (Fig. 9c). The total vegetated belt in the dry scenario does not deviate much from the reference scenario, while the climateenhanced extremes scenario results in a vegetated belt extending further into the floodplain (Fig. 9). The combination of climate change and dams reveals interesting vegetation patterns: under the reversed dam scenario, climate-enhanced extreme events show a smaller vegetated belt than the drier climate scenario for a large period of time. Under the stable flow regime the climate scenarios remarkably result in an opposite pattern (Fig. 9d).

Thus, stabilized flow by dams causes shifts of vegetation to higher elevations and laterally constrains development riparian trees, of which the effect is strongest, and thus most deteriorating, with reversed flow seasonality. Extreme events increase the vegetated belt and causes a shift of vegetation towards higher elevations on the floodplain, drying gives an opposite effect by shifting vegetation towards lower elevations. The combination of the stable dam and climatic drying shows the largest negative cumulative effects.

\subsection{Habitat suitability}

The reference scenario shows large areas with good habitat suitability (HSI > 0.5) for hardwood and grassland. For fish and wetland species the suitable area is smaller. However, when habitat stability for vegetation types, and resilience for pike, is taken into account as additional requirement, the area with persistent suitable habitat changes considerably for all species (Fig. 10a, b and Table 5).

The suitable area for grassland declines, because parts of the habitat are not stable for a sufficient number of years due to morphodynamic disturbances. The suitable area for macrophytes and helophytes declines as well, albeit less than for grassland. The suitable area for pike has increased due to their ability to survive several years without spawning opportunity, and - apparently - unsuitable conditions for spawning did not occur during more than 8 years in a row.

The percentage of good habitat in the reference scenario of most riparian and aquatic species, except grassland and hardwood forest, shows a similar periodicity as the lower areas of the bed level (Fig. 10c 

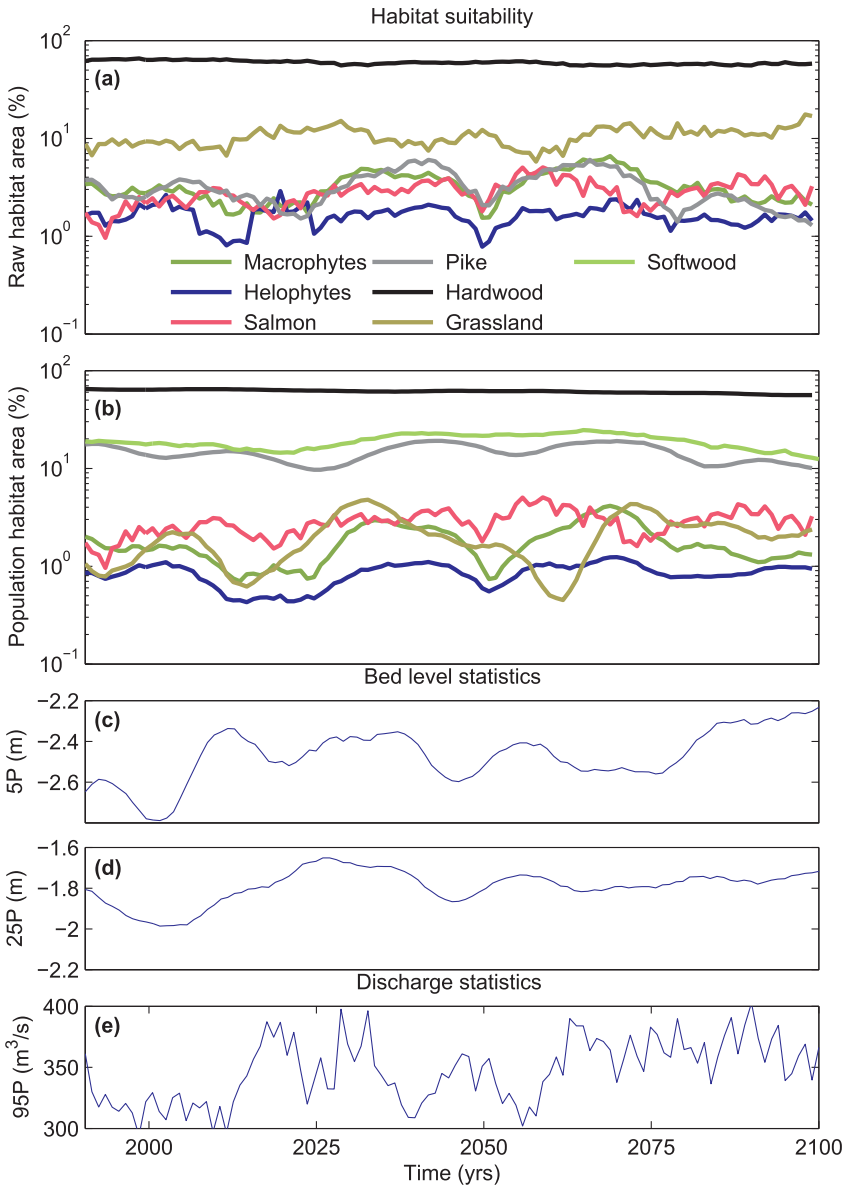

Fig. 10. Habitat suitability and hydro-morphodynamic statistics in the reference scenario. a) Suitable habitat area without population response, b) suitable habitat area taking temporal habitat stability requirements into account (see methods section for further explanation), c) 5th percentile of the bed level, d) 25th percentile of the bed level, e) 95th percentile of the discharge. See detailed description in Section 2.4.2

Table 5

Suitable habitat of the reference scenario with and without population response.

\begin{tabular}{lll}
\hline Species & HSI absolute (\%) & HSI population response (\%) \\
\hline Macrophytes & 2.8 & 1.5 \\
Helophytes & 1.3 & 0.8 \\
Salmon & 2.1 & 2.1 \\
Pike & 2.9 & 14 \\
Hardwood & 59 & 53 \\
Grassland & 10 & 1.1 \\
\hline
\end{tabular}

and d). This indicates that channel depth is a major control for suitable habitat for riparian and aquatic species as opposed to the seasonally variable water depth and flow velocity, which are the main input variables for the habitat suitability models. However, there is no linear correlation between channel depth and habitat suitability but rather an optimum curve: when the channel becomes too deep or too shallow, suitability declines.

When habitat suitability in all scenarios is compared to the reference scenario we see distinct differences (Fig. 11). A decreasing discharge under the dry scenario is bad for both fish species and riparian vegetation, while all other vegetation groups seem to profit. Under the extreme climate change scenario there is an initial peak in suitability for wetland vegetation, but eventually the suitable habitat area decreases to values below reference level. Riparian grassland and young hardwood, which are representatives for intermediate disturbed conditions, benefit and the suitable area for salmon decreases. A striking result is that wetland vegetation strongly benefits from the reversed flow regime, while all other species, except hardwood forest are negatively affected, particularly both fish species. Under the stable flow regime there is an initial peak in suitable habitat for salmon and wetland vegetation, but eventually a decline. Grassland and hardwood forest benefit in the stable dam scenario, while grassland is drastically reduced under a reversed flow regime. Combinations of dams and climate change do not show uni-directional responses, in some cases habitat suitability increases by drying or extreme events and in other cases it decreases.

To summarize the long-term ecological effects of all flow alteration regimes, we present a matrix representing how the scenarios per species and species group relate to the reference scenario (Fig. 12). The results suggest that there are many adaptation timescales as well as trends with a certain periodicity, likely due to decadal trends in discharge, but regardless, the climate change effects are strongest at the end of the simulation and therefore we use the last interval (years 2067-2100) as an indicator of long-term effects. Fig. 12 shows that the impacts of a reversed flow regime deviate most from the natural situation for all species and species groups. Extreme events generate larger deviations from the reference scenario than a general drying trend, especially for the aquatic and wetland species. The combination of a stable flow regime with additional drying causes several remarkable changes when compared to both individual single-pressure scenarios, generating a positive deviation for helophytes and negative deviations for pike and softwood.

\section{Discussion}

In the following sections we will discuss effects of flow alteration on bio-geomorphodynamic processes and interactions. First we compare our model results to observations reported in literature. Then we discuss the ecological effects of multiple flow alteration regimes based on the main hydrodynamic drivers: decreased hydrodynamics, increased hydrodynamics and mismatch between ecological processes and flow timing. We end with a reflection on the novel insights emerging from this study and how these results can be of value for river basin management and environmentally friendly dam operation.

\subsection{Comparison between modelled and observed effects of flow alterations}

\subsubsection{Flow alteration by dams}

The main hydrological effect of flow alteration by dams is an immediate redistribution of river discharge over the year, expressed as a damped flow regime or seasonally reversed flow. Our modelling results show that damping of extreme flows by dams leads to reduced morphodynamic activity, channel incision, reduced seedling recruitment, aging and decline of riparian vegetation (Figs. 5a, 7c, 7d and 6). This is in general agreement with many field studies on geomorphological and vegetation response after dam construction in a variety of river systems (e.g. overviews in Williams and Wolman (1984), Rood and Mahoney (1990), Petts and Gurnell (2005), Poff and Zimmerman (2010)). Incision is usually caused by sediment starvation due to the capture of sediment upstream in the dam reservoir, limiting the sediment load into the system while the river still has enough stream power left to erode the bed behind the dam (Kondolf, 1997). Here we find similar but less severe far-field effects with a reduction in total morphodynamic activity due to elimination of large discharge peaks that account for a large proportion of the sediment transport within the river reach (Fig. 5b). Moreover, since the variability of the flow is reduced, the area that is flooded, i.e. the wetted area, declines (Fig. 9a), which leads to persistent concentration of the flow over a relatively smaller area and in turn bed degradation (Williams and Wolman, 1984). This process is correctly predicted by our model and shows that even without reducing the 


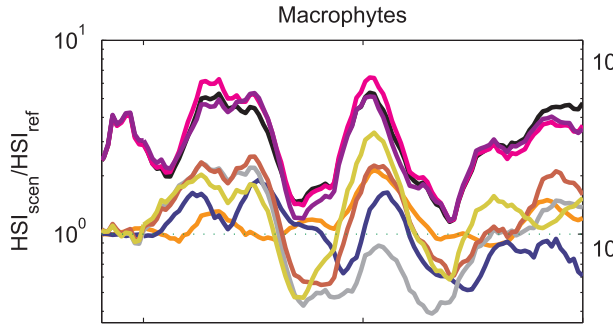

Pike

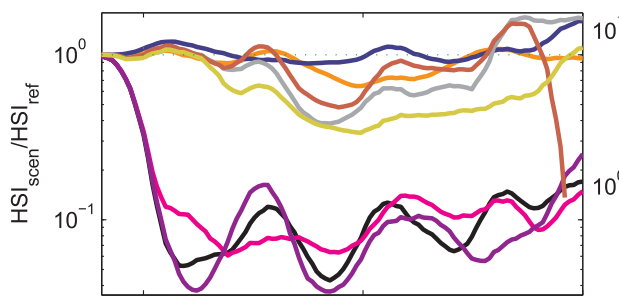

Grassland

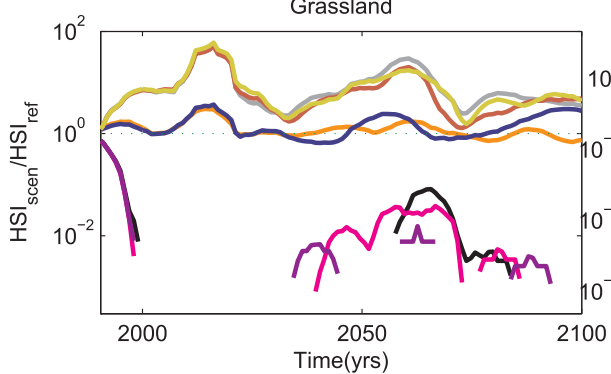

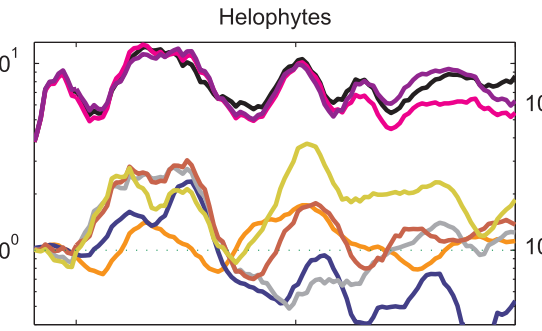

Hardwood young

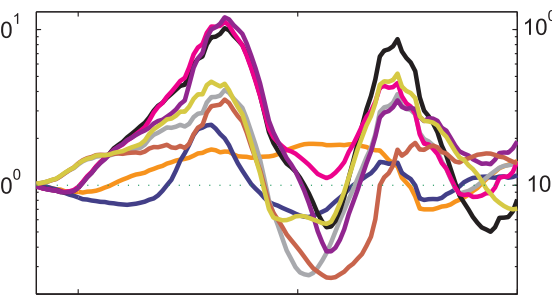

Softwood

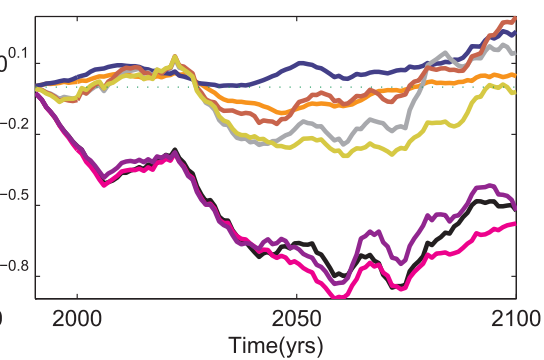

Salmon

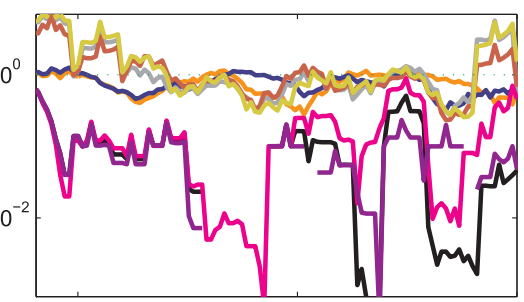

Hardwood old

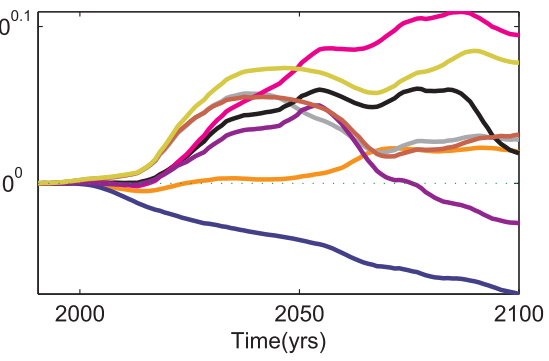

Fig. 11. Percentage of suitable habitat (HSI > 0.5) for all species and species groups as a fraction compared to the reference scenario: values above one indicate higher suitability than the reference scenario. Softwood is the cover of the interactively modelled Salicaceae species. See detailed description in Section 2.4 .2

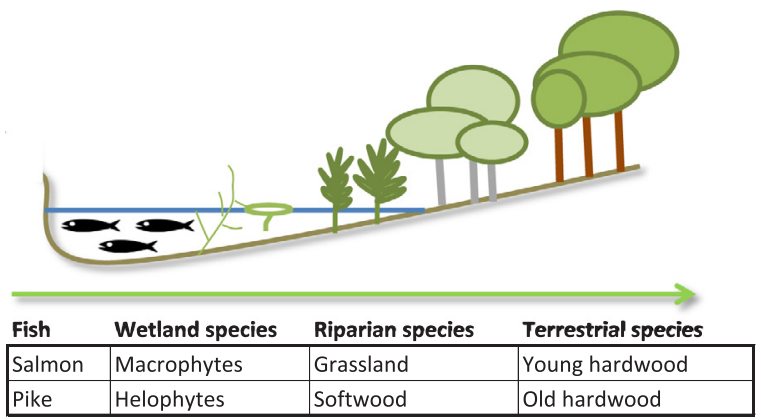

\begin{tabular}{|c|c|c|c|c|c|c|c|c|c|c|}
\hline \multirow{2}{*}{\multicolumn{6}{|c|}{$\begin{array}{l}50 \mathrm{P} \text { reference }<\text { value }<75 \mathrm{P} \text { reference } \\
\text { value }>75 \mathrm{P} \text { reference }\end{array}$}} & & \multicolumn{4}{|c|}{$25 \mathrm{P}$ reference $<$ value $<50 \mathrm{P}$ reference } \\
\hline & & & & & & & \multicolumn{4}{|c|}{ value $<25 \mathrm{P}$ reference } \\
\hline \multicolumn{4}{|c|}{ Natural } & \multicolumn{4}{|c|}{ Dam stable } & \multicolumn{3}{|c|}{ Dam reversed } \\
\hline 2.33 & 1.48 & 1.52 & 2.06 & 1.67 & 1.62 & 6.54 & 2.88 & & 4.64 & 3.92 \\
\hline 12.3 & 0.87 & 17.2 & 48.9 & 16.6 & 1.03 & 18.7 & 52.1 & 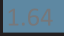 & 6.68 & 56.2 \\
\hline \multicolumn{4}{|c|}{ CCDry } & \multicolumn{4}{|c|}{ Dam stable + CCDry } & \multicolumn{3}{|c|}{ Dam reversed + CCDry } \\
\hline 1.64 & 1.53 & 1.67 & 2.44 & 1.59 & 2.09 & 5.6 & 3.17 & 0.01 & 4.13 & 2.81 \\
\hline 12.3 & 0.94 & 18.7 & 51.2 & 29 & 1.69 & 12.2 & 58 & & 4.88 & 62.5 \\
\hline \multicolumn{4}{|c|}{ CCExtreme } & \multicolumn{4}{|c|}{ Dam stable + CCExtreme } & \multicolumn{3}{|c|}{ Dam reversed + CCExtreme } \\
\hline & 1.16 & 2.69 & 2.2 & 1.2 & 1.67 & 4.36 & 3.7 & & 4.36 & 3.51 \\
\hline 15.9 & 0.47 & 22.9 & 42.7 & 15.1 & 1.08 & 20.9 & 51.6 & $1 /$ & 6.88 & 47.5 \\
\hline
\end{tabular}

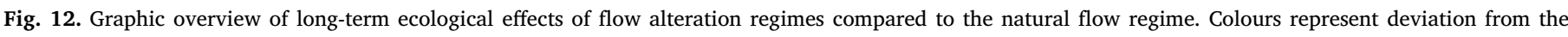

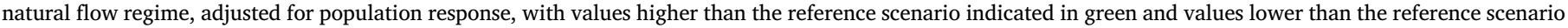

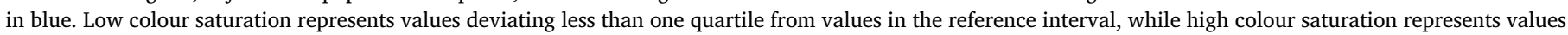
with higher deviations. Values were calculated as median values over the last interval (years 2067 to 2100 ).

sediment load into the system, channel incision occurs downstream of dams.

Under the reversed dam scenario wider, shallower channels develop over time, increasing the width-depth ratio. This might be caused by a reduction of vegetation abundance and a shift of vegetation towards higher floodplain elevations, together with an elimination of vegetation at lower floodplain elevations. This may lead to easier diffusion of the flow over the floodplain. The stable dam scenario also shows a shift of vegetation survival towards higher elevations on the floodplain, but does not eliminate all vegetation at lower floodplain elevations. Vegetation could therefore still cause flow concentration in the channel and therefore better maintains the incised channel shape. Other studies show that a stabilized flow regime with resulting lower morphodynamic activity creates less suitable areas for seedling establishment and higher mortality rates, which eventually leads to aging vegetation (Rood and Mahoney, 1995; Polzin and Rood, 2000; Dixon et al., 2012).
We observe this effect clearly in both dam scenarios, where the colonization peaks of seedlings are reduced, vegetation abundance declines and the share of older vegetation increases (Figs. 4 and 6). The width of the vegetated belt initially decreases in both scenarios (Fig. 9c). This implies that vegetation on the floodplain is more confined, and the total extent of vegetation is becoming increasingly affected by flood or low flow events because there is less area to buffer the change. Studies show that, when less area is prone to regular flooding, there is an increasing abundance of terrestrial species and vegetation encroachment towards the channel (Williams and Wolman, 1984; Stromberg et al., 2010; Dolores Bejarano et al., 2011). These responses are clearly reflected in our results (Figs. 11 and 12).

\subsubsection{Flow alteration by climate change}

Flow alteration due to climate change is more gradual than the effect of dams. The two climate change scenarios give opposite results in 
terms of morphodynamic activity and riparian vegetation development. Climate change with a drying trend decreases morphodynamic activity, while extreme events increase morphodynamic activity (Fig. 5a). This is a direct effect of the gradually decreasing or increasing discharges in these scenarios. Extreme events contribute to channel incision due to higher sediment transport rates in the channel, expressed by a lower width-depth ratio. Decreasing discharge initially creates narrower, deeper channels, causing a reduction in width-depth ratio. Due to reduced discharge, water levels decrease over time, leading to higher width-depth ratios (Fig. 7c).

In the drying scenario, we observe a shift of vegetation towards lower elevations on the floodplain, which is comparable to results found in Martínez-Fernández et al. (2018). The width of the vegetated belt does not differ from the reference scenario but the vegetation shows a decrease in vegetated area due to reduced seedling recruitment. Drying causes narrower channels, an effect which might be strengthened by the downward shifting vegetation. In agreement with literature (Garssen et al., 2014), we predict that the vegetation composition is shifting from riparian species towards more terrestrial species.

Extreme events by climate change are expected to rearrange channel patterns and influence species abundance and distributions (Gibson et al., 2005; Poff et al., 2010; Death et al., 2015). We find that increasing extreme events lead to a shift of increased seedling establishment at higher elevations, widening the vegetation belt and increasing its total abundance (Figs. 6 and 9c). Again, due to increased vegetation abundance across the whole lateral floodplain gradient, flow is focused more into the channels, leading to narrower, deeper channels. Several other modelling studies have predicted similar shifts in vegetation elevation ranges and belt sizes following increasing extremes due to climate change (Ström et al., 2012; Mosner et al., 2015). However, these range and abundance shifts of vegetation are only possible if the floodplain gradient is not too steep and the valley is wide. Our modelling results therefore suggest that such positive effects would be limited in rivers with narrow, confined valleys. Although the study of Mosner et al. (2015) was performed in a more confined system, they predict very heterogeneous responses, among others a decline in hardwood forest and helophytes. Results from our extreme scenario also show the most heterogeneous results of all single-pressure scenarios, including a decline in hardwood forest and helophytes due to increased dynamics (Fig. 12). Battin et al. (2007) concluded that Chinook salmon habitat declines in the Pacific Northwest river basin are likely due to increased peak flows during egg incubation. In our scenario, salmon habitat is declining due to increasing high flows during spawning.

\subsection{Bio-geomorphodynamic effects of multiple flow alterations}

Our model results show that flow alteration has two main consequences: it affects the magnitude and timing of morphodynamic processes and it affects the location and density of riparian vegetation development, which in turn determines the eco-engineering capacity within the system. Both of these effects are interdependent and operate at different timescales. Continuous bio-geomorphodynamic interactions create a heterogeneous and dynamic landscape pattern that can be utilized by fluvial species. Habitat suitability of fluvial species depends on their requirements which are linked to the morphological template of the river landscape combined with the flow dynamics. For a sustainable population, habitat requirements have to be met at critical moments in time. The habitat suitability of several aquatic and riparian species is tightly linked to the hydrological and morphological variability. Channel depth shows a similar variability as habitat suitability, albeit with a certain optimum curve, meaning that very deep channels as well as very shallow channels reduce habitat suitability for the species considered here (Fig. 10). These dynamic changes in channel pattern are caused by meander migrations and chute cut-offs, that locally alter channel depth (Fig. 7a and b). The geomorphological template thus determines the biotic composition of an ecosystem (e.g. Richter and Richter, 2000; Bunn and Arthington, 2002). Cienciala and Pasternack (2017) state that the effects of flow alteration on the duration, frequency and magnitude of floodplain inundation are larger than river topography, but the topography dictates the sensitivity to these changes. Indeed, our results confirm that in all scenarios habitat suitability is affected in multiple ways by changes in river morphology (Figs. 11 and 12). Simulating combined effects of climate change and dams allows us to investigate how a gradual change after an acute flow alteration might strengthen or weaken the bio-morphological response compared to the single disturbance. However, we do not observe clear cumulative or decreasing morphodynamic trends when flow alteration scenarios are combined. This suggests that multiple flow alteration pressures render unexpected hydro-morphodynamic results due to nonlinear effects that are in turn reflected in the ecological response. In the sections below, the ecological effects of these combined pressures are discussed based on three main hydrodynamic drivers.

\subsubsection{Effect of decreasing hydrodynamics}

We find that decreasing hydrodynamics due to less discharge variability, i.e. due to by dams, or gradually reducing water levels, i.e. resulting from climatic drying, cause an increase in abundance of terrestrial species due to a decline in wetted area (Figs. 9a and 12). This leads to reduced connectivity between channel and floodplain, which might negatively impact fish species (Gibson et al., 2005). We did not take this into account in the habitat suitability assessment, but it is likely that there will be an additional negative effect due to the isolation of floodplain lakes. In addition, results show that wetland species also benefit from reduced hydrodynamics due to the creation of larger undisturbed habitats. When drying occurs in dammed systems, hydrodynamics are even further reduced and ecological changes become more severe. When drying occurs in a damped flow regime, the vegetation becomes more confined on the floodplain, while drying increases the vegetated belt in the scenario with reversed flow seasonality (Fig. 9). Drying has negative long-term consequences in dammed systems by reducing seedling recruitment, leading to aging and eventually a decline in riparian vegetation cover (Figs. 6 and 12).

\subsubsection{Effect of increasing extremes in high and low flow}

We find that increased discharge variability, in our study reflected in the extreme events scenario, increases seedling recruitment. This creates more area that is available for vegetation settlement in both dam scenarios (Figs. 6 and 12) due to gradually increasing discharges during the seed dispersal season (Fig. 8b). However, the vegetated belt is reduced in the scenario with reversed flow seasonality, indicating that the vegetation becomes more confined on the floodplain by hydromorphodynamic pressures. The opposite pattern is found in the stable dam scenario. Increasing hydrodynamics in dammed systems have little additional effects on habitat area of fish, which is slightly reduced, and habitat area of wetland species, which is slightly increased. There is, however, a decrease in terrestrial species, especially in combination with the reversed dam scenario. This is most likely due to the larger variation in discharge in the reversed dam scenario plus relatively high morphodynamic activity, which negatively affects the long-term stability of the system necessary for hardwood development. This shows that increasing dynamics decreases the window of opportunity for terrestrial species.

\subsubsection{Effect of flow mismatch}

The model results demonstrate that timing of flow events relative to timing of critical life-history events has major effects, which is in general agreement with literature. Studies have shown that species are affected differently based on the magnitude and direction of flow alteration during the timing of their critical life history events (Bunn and Arthington, 2002; Gibson et al., 2005; Poff and Zimmerman, 2010; 
Death et al., 2015) and that synchrony between flow seasonality and seed dispersal timing is important for successful seedling establishment (Mahoney and Rood, 1998; Karrenberg et al., 2002). The scenario with reversed flow seasonality shows the strongest deviation from the undisturbed conditions, thus can be considered the most detrimental. Here, characteristic riparian vegetation is replaced by terrestrial species, so there is a shift towards species groups that are less characteristic for dynamic river environments. This is because the bed level elevation for seedling settlement is low compared to the discharges during summer and winter and as a result it falls outside the recruitment window. This causes high flooding mortality of the seedlings in lower areas and reduced areal cover of riparian vegetation (Fig. 8c, e and g). So, the reversed flow seasonality leads to a larger mismatch than flow stabilization alone. In these systems, riparian vegetation is not able to benefit from the increased wetted area caused by larger flow variability since the mismatch is the dominant driver in determining the vegetation composition.

Model results show that several fluvial species are negatively affected by disrupted flow seasonality, while others benefit. For wetland vegetation, which is an indicator for low dynamic conditions, habitat suitability increases, while for pike, which also prefers low dynamic conditions, it decreases. This is because water depth combined with morphodynamic activity are considered the limiting factors for the wetland species in this study, and a reversed flow regime eliminates these limitations during the critical timing for these species in spring and summer. Spawning of pike takes place during late winter and early spring when the flow is unnaturally low, reducing the suitable spawning area.

Riparian grassland is drastically reduced under a reversed flow regime. This is likely due to the combination of a heavily incised river with a larger discharge variability, draining the system quite rapidly in times of lower flows. Since we model riparian grassland adapted to regular flooding, the conditions will often be too dry for this vegetation type. This shows that the reversed flow regime creates conditions that limit the existence of a certain group of species that is adapted to medium levels of inundation. Here, the lower floodplain areas are not suitable because they are too frequently inundated, while the higher floodplain areas are not suitable due to too little flooding. Habitat originally occupied by riparian grassland would than likely be replaced by mesic grasslands that prefer less frequently flooded areas (Leyer, 2005). These results show that when the synchrony between critical life history events of riparian species and the flow regime is disturbed, unexpected results can occur that may differ between species that prefer similar habitat types.

\subsection{Opportunities for management}

In the future, dams will be constructed for flood control, power generation and for securing water supplies (Petts and Gurnell, 2005). Therefore, many river systems will respond to flow regimes imposed by dams combined with a climatic trend creating extremes in high and low flows. Dams can be used to mitigate the effects of climate change by adjusting the discharge regime (Muller, 2007), although this can sometimes lead to conflicts between required economic functions and in stream flow requirements (Payne et al., 2004). Intuitively, mitigating climate change by adjusting dam operating regimes is only possible in case of water excess where extreme high flows can be dampened by the dam. When the water supply is reduced by a drying climate, a discrepancy occurs between water storage functions of the dam and mimicking of natural flow regimes. The ecological effect of climate change alone is expected to be smaller than the acute effect of dams (Mittal et al., 2015). Still, in case of increased intensity of high and low flows, we find that the aquatic and wetland species are more heavily affected than in a system with a stabilized flow regime. Nevertheless, climate change can further decrease the resilience of ecosystems that are already under pressure (Palmer et al., 2008; Staudt et al., 2013).
Therefore, river managers could pro-actively evaluate trends in discharges to estimate the direction of change in their river systems and take measures to prevent further deterioration.

Our study is the first to investigate the long-term quantitative effects of combinations of dams and climate change and reveals unexpected behaviour and trends. Results indicate that complex interaction effects at different adaptive timescales are at play and that the bio-geomorphological state of the system, i.e. the river topography combined with vegetation pattern, strongly influences temporal morphodynamics. This indicates that it might be too simplistic to sum up effects of singlepressure flow alteration scenarios, since the system is continuously adapting to new circumstances which can give unexpected results. Simplistic conceptual and rule-based models therefore likely miss-predict long-term consequences of changing flow regimes originating from multiple sources. Based on the insights from this study, we formulate several propositions and possible consequences for river managers aiming to cope with climate change in dammed systems.

1. Larger, heterogeneous floodplains are necessary for the ecosystem to cope with extreme discharges and to benefit from increased dynamics.

Dams alter river morphodynamics, which spatially constrains fluvial species. This decreases the buffer capacity of the system, meaning that the system provides fewer suitable conditions for certain species or functional groups in the riparian zone. Buffer capacity is therefore strongly linked to landscape heterogeneity. This negative effect of decreased buffer capacity was recognized in dam-impaired systems (Palmer et al., 2008). We show that increased extreme events can rejuvenate riparian vegetation on wider floodplains, e.g. in lowland rivers, but this effect is limited in valley-confined rivers. Floodplain widening will also better protect against flooding of human structures, since they can store and discharge more water.

2. Successful restoration and climate change mitigation may be achievable by modified flow event timing and flow magnitude in dam operating scenarios that accommodate habitat requirements of chosen key-species.

Our results show that increased high floods can rejuvenate riparian vegetation downstream of a dam, but this measure will be more effective in a system when there is still a natural seasonality. In a reversed-seasonality flow regime, seedling recruitment will not be successful because the synchrony between seed dispersal timing and high flows is disrupted, which is the dominant factor in determining the riparian vegetation structure. Therefore, particularly aspects of seasonality in the habitat requirements of the main species groups or key species have to be accommodated (Lytle and Merritt, 2004). Designing new dam operating regimes that more resemble the natural flow regime could potentially be ecologically, socially and commercially beneficial (Richter and Thomas, 2007). However, optimal conditions sometimes conflict between species, so managers will need advice which species to choose for which the system will be optimized and how a new flow regime can be designed without jeopardizing the main functions for which the dam was built in the first place.

3. In order to evaluate long-term effects of flow alterations by single- or multiple flow alteration pressures, geo-morphodynamic interactions need to be coupled to habitat suitability models.

Our modelled river system clearly exhibits a morphodynamic signature in the changing habitat suitability with a 27 years periodicity. This period depends on multiple interacting elements that influence river pattern dynamics, e.g. vegetation development, stream power and sediment type that act on different timescales and influence river migration and chute cut-offs. These long timescales must be taken into account in assessments of habitat restoration success and models such as ours are valuable heuristic tools to assess long-term effects of flow alteration on dynamic interactions between 
vegetation and hydro-morphodynamics at such long ecological timescales.

\section{Conclusions}

Flow alteration affects morphodynamic processes and interdependent riparian vegetation development by changing the magnitude, timing and spatial distribution of discharges. As a result, landscape patterns and their dynamics are rearranged, which affects the suitable habitat area for fluvial species.

Landscape patterns change as follows. Acute flow stabilization creates channel incision, even if upstream sediment supply is not reduced, which directly reduces and limits seedling recruitment of riparian vegetation spatially. This causes aging of the riparian corridor and increased succession towards terrestrial species. The vegetated belt narrows by desiccation on the higher parts of the floodplain and morphodynamic activity and flooding on the lower parts of the floodplain, which reduces the resilience of the riparian corridor. In spite of these direct adverse effects, a gradual flow alteration with increasing high flows and low flows seems to be beneficial under unconfined conditions by shifting and increasing the riparian vegetation belt higher up the floodplain. A gradual drying trend shows a slight decrease in riparian vegetation recruitment and a shift towards lower elevations on the floodplain, exposing vegetation to greater risk by mortality due to extreme events.

Changing dynamics of altered flow, particularly the shift in timing of the flows linked to the critical life history events, strongly affect the magnitude of the response of fluvial species. An acute flow alteration with reversed flow seasonality appeared to be the most detrimental scenario. This acutely disrupts the synchrony of vital life history processes and flows necessary to meet habitat requirements. For riparian vegetation, this leads to a mismatch between seed dispersal timing and optimal hydrological conditions for survival, resulting in a total decline of the riparian vegetation cover. Also, the synchrony between the timing of spawning and egg incubation of pike and salmon and resulting habitat is disrupted, leading to a decline of both fish species. On the other hand, wetland species for which prolonged water availability is the most limiting factor during their growth season, thrive in these changed conditions.

Combinations of acute flow alteration by dams and gradual alteration by climate change do not have straightforward and uni-directional effects on species. Some species exhibit the trends of gradual climatic change whereas other species show acute effects of the dams or combinations. The effects of flow alteration can therefore not be extrapolated to riparian vegetation and habitat suitability of fluvial species by simply adding up effects of isolated flow alteration scenarios. One important reason is that dynamic bio-geomorphological interactions with multiple adaptation timescales determine river morphology and as a result cause changes in timing, magnitude and frequency of flooding and drought events which in turn affect habitat suitability.

Our results show that climate change sometimes further deteriorate the hydro-morphodynamic and ecological state of dammed systems. Under specific conditions, adverse effects of climate change can be mitigated by tuned flow alteration by dams. This offers interesting opportunities to study how dam operating regimes can be adapted to mitigate effects of climate change.

\section{Acknowledgements}

We kindly thank Dr. Gerben van Geest (Deltares) for contributing to the dose-effect relations of macrophytes and helophytes. Two anonymous reviewers are thanked for valuable discussion and reviewing of the previous version of this manuscript. This work was funded by REFORM (FP7 Grant Agreement 282656). The authors contributed in the following proportions to conception and design, model running, analysis and conclusions, and manuscript preparation: $\mathrm{MvO}$ (60\%,
$100 \%, 60 \%, 65 \%)$, MGK (10\%, 0\%, 15\%, 15\%), TB (10\%, $0 \%, 5 \%, 5 \%)$, GG $(10 \%, 0 \%, 5 \%, 5 \%)$ and $\mathrm{HM}(10 \%, 0 \%, 15 \%, 10 \%)$.

\section{References}

Azami, K., Suzuki, H., Toki, S., 2004. Changes in riparian vegetation communities below a large dam in a monsoonal region: futase dam, Japan. River Res. Appl. 20, 549-563. Baptist, M., Babovic, V., Rodriguez Uthurburu, J., Uittenbogaard, R., Mynett, A., Verwey, A., 2007. On inducing equations for vegetation resistance. J. Hydraul. Res. 45 (4), 435-450.

Battin, J., Wiley, M.W., Ruckelshaus, M.H., Palmer, R.N., Korb, E., Bartz, K.K., Imaki, H., 2007. Projected impacts of climate change on salmon habitat restoration. Proc. Nat. Acad. Sci. 104 (16), 6720-6725.

Braatne, J., Rood, S., Heilman, P., 1996. Life history, ecology and conservation of riparian cottonwoods in north America. In: Stettler, R., Bradshaw, G., Heilman, P., Hinckley, T. (Eds.), Biology of Populus and its Implications for Management and Conservation, (Part I). NRC Research Press, Ottawa, Ch. 3, pp. 57-85.

Brucet, S., Boix, D., Nathansen, L.W., Quintana, X.D., Jensen, E., Balayla, D., Meerhoff, M., Jeppesen, E., 2012. Effects of temperature, salinity and fish in structuring the macroinvertebrate community in shallow lakes: Implications for effects of climate change. PLoS One 7 (2).

Bunn, S.E., Arthington, A.H., 2002. Basic principles and ecological consequences of altered flow regimes for aquatic biodiversity. Environ. Manage. 30 (4), 492-507.

Cienciala, P., Pasternack, G., 2017. Floodplain inundation response to climate, valley form, and flow regulation on a gravel-bed river in a Mediterranean-climate region. Geomorphology 282, 1-17.

Clarke, K.D., Pratt, T.C., Randall, R.G., Dave, A., Smokorowski, K.E., 2008. Validation of the Flow Management Pathway : Effects of Altered Flow on Fish Habitat and Fishes Downstream from a Hydropower Dam. Tech. rep., Northwest Atlantic Fisheries Center, St. John's.

Dankers, R., Feyen, L., 2008. Climate change impact on flood hazard in Europe: an assessment based on high-resolution climate simulations. J. Geophys. Res. Atmos. 113, $1-17$.

De laak, G., 2007. Kennisdocument Atlantische zalm, Salmo salar (in Dutch). Tech. rep. Sportvisserij Nederland, Bilthoven.

De Laak, G.A.J., Van Emmerik, W.A.M., 2006. Kennisdocument snoek, Esox lucius (in Dutch). Tech. rep. Sportvisserij Nederland, Bilthoven.

Death, R.G., Fuller, I.C., Macklin, M.G., 2015. Resetting the river template: the potential for climate-related extreme floods to transform river geomorphology and ecology. Freshw. Biol. 60, 2477-2496.

Dikker, T., 1974. Een plantkundige beschrijving, de levenswijze en de eisen, die het riet stelt ten aanzien van zijn omgeving (in Dutch). Tech. rep. Rijksdienst voor de IJsselmeerpolders, Lelystad.

Dixon, M.D., Johnson, W.C., Scott, M.L., Bowen, D.E., Rabbe, L.A., 2012. Dynamics of plains cottonwood (Populus deltoides) forests and historical landscape change along unchannelized segments of the Missouri River, USA. Environ. Manage. 49, 990-1008.

Dolores Bejarano, M., Nilsson, C., González Del Tánago, M., Marchamalo, M., 2011. Responses of riparian trees and shrubs to flow regulation along a boreal stream in northern Sweden. Freshw. Biol. 56, 853-866.

Dynesius, M., Nilsson, C., 1994. Fragmentation and flow regulation of river systems in the Northern third of the world. Science 266 (5186), 753-762.

Garssen, A.G., Verhoeven, J.T.A., Soons, M.B., May 2014. Effects of climate-induced increases in summer drought on riparian plant species: a meta-analysis. Freshw. Biol. 59, 1052-1063.

Geerling, G., Ragas, A., Leuven, R., van Den Berg, J., Breedveld, M., Liefhebber, D., Smits, A., 2006. Succession and rejuvenation in floodplains along the river Allier (France). Hydrobiologia 565, 71-86.

Geest, G.V., Teurlincx, S., 2010. Invloed van peilfluctuaties op waterplanten in de hoofdstroom en permanent verbonden wateren langs de Rijn (in Dutch). De Levende Natuur.

Gibson, C.A., Meyer, J.L., Poff, N.L., Hay, L.E., Georgakakos, A., 2005. Flow regime alterations under changing climate in two river basins: Implications for freshwater ecosystems. River Res. Appl. 21, 849-864.

Gurnell, A., 2014. Plants as river system engineers. Earth Surf. Proc. Land. 39 (1), 4-25.

Haasnoot, M., van de Wolfshaar, K.E., 2009. Combining a conceptual framework and a spatial analysis tool, HABITAT, to support the implementation of river basin management plans. Int. J. River Basin Manage. 7 (4), 295-311.

Inskip, P., 1982. Habitat suitability index models: northern pike. Tech. rep., U.S. Dept. Int., Fish Wildl. Serv.

IPCC, 2000. IPCC special report. Emissions scenarios. Summary for policymakers. Tech. rep.

Karrenberg, S., Edwards, P.J., Kollmann, J., 2002. The life history of Saliacaceae living in the active zone of floodplains. Freshw. Biol. 47, 733-748.

Kleinhans, M.G., van den Berg, J.H., 2011. River channel and bar patterns explained and predicted by an empirical and a physics-based method. Earth Surf. Proc. Land. 36, $721-738$.

Klijn, F., Van Rooij, S.A., Haasnoot, M., Higler, L.W.G., B., Nijhof, S.J., B., 2002. Ruimte voor de Rivier, Ruimte voor de Natuur? (In Dutch). Tech. rep., Alterra, WL/delft Hydraulics, Wageningen, Delft.

Kondolf, G.M., 1997. Hungry water: effects of dams and gravel mining on river channels. Environ. Manage. 21 (4), 533-551.

Lesser, G., Roelvink, J., van Kester, J., Stelling, G., 2004. Development and validation of a three-dimensional morphological model. Coast. Eng. 51, 883-915.

Leyer, I., 2005. Predicting plant species ' responses to river regulation : the role of water 
level fluctuation. J. Appl. Ecol. 42, 239-250.

Li, H., Reynolds, F.F., 1993. A new contagion index to quantify spatial patterns of landscapes. Landscape Ecol. 8 (3), 155-162.

Lytle, D.A., Merritt, D.M., 2004. Hydrologic regimes and riparian forests: a structured population model for Cottonwood. Ecology 85 (9), 2493-2503.

Maas, G.J., 1998. Benedenrivier-Ecotopen-Stelsel (in Dutch). Tech. rep. Rijkswaterstaat RIZA, Arnhem.

Mahoney, J.M., Rood, S.B., 1998. Streamflow requirements for Cottonwood seedling recruitment - an integrative model. Wetlands 18 (4), 634-645.

Mantyka-Pringle, C.S., Martin, T.G., Moffatt, D.B., Linke, S., Rhodes, J.R., 2014. Understanding and predicting the combined effects of climate change and land-use change on freshwater macroinvertebrates and fish. J. Appl. Ecol. 51, 572-581.

Martínez-Fernández, V., Van Oorschot, M., De Smit, J., González del Tánago, M., Buijse, A.D., 2018. Modelling feedbacks between geomorphological and riparian vegetation responses under climate change in a Mediterranean context. Earth. Surf. Proc. Land.

McGarigal, K., Marks, B., 1995. FRAGSTATS: Spatial Analysis Program for Quantifying Landscape Structure. Gen Tech. Rep.. USDA Forest Service.

McShane, R.R., Auerbach, D.A., Friedman, J.M., Auble, G.T., Shafroth, P.B., Merigliano, M.F., Scott, M.L., Poff, N.L., 2015. Distribution of invasive and native riparian woody plants across the western USA in relation to climate, river flow, floodplain geometry and patterns of introduction. Ecography 38, 1254-1265.

Merritt, D., Cooper, D., 2000. Riparian vegetation and channel change in response to river regulation: A comparative study of regulated and unregulated streams in the Green River Basin, USA. Regulated Rivers-Res. Manage. 16, 543-564.

Middelkoop, H., Alabyan, A.M., Babich, D.B., Ivanov, V.V., 2015. Post-dam Channel and Floodplain Adjustment along the Lower Volga River, Russia, in Geomorphic Approaches to Integrated Floodplain Management of Lowland Fluvial Systems in North America and Europe, edited by P.F. Hudson and H. Middelkoop, pp. 245-264, Spring, New York.

Mittal, N., Bhave, A.G., Mishra, A., Singh, R., 2015. Impact of human intervention and climate change on natural flow regime. Water Resour. Manage 30, 685-699.

Mosner, E., Weber, A., Carambia, M., Nilson, E., Schmitz, U., Zelle, B., Donath, T., Horchler, P., 2015. Climate change and floodplain vegetation-future prospects for riparian habitat availability along the Rhine River. Ecol. Eng. 82, 493-511.

Muller, M., 2007. Adapting to climate change: water management for urban resilience. Environ. Urbanization 19 (1), 99-113.

Nilsson, C., Reidy, C., Dynesius, M., Revenga, C., 2005. Fragmentation and flow regulation of the world's large river systems. Science 308 (5720), 405-408.

Nilsson, C., Svedmark, M., 2002. Basic principles and ecological consequences of changing water regimes: riparian plant communities. Environ. Manage. 30, 468-780.

Palmer, M.A., Reidy Liermann, C.A., Nilsson, C., Florke, M., Alcamo, J., Lake, P.S., Bond, N., 2008. Climate change and the world's river basins: anticipating management options. Front. Ecol. Environ. 6 (2), 81-89.

Payne, J., Wood, A., Hamlet, A., 2004. Mitigating the effects of climate change on the water resources of the Columbia River basin. Clim. Change 62, 233-256.

Peters, B., 2002. Successie van natuurlijke uiterwaardlandschappen (Dutch). Tech. rep. Bureau Drift \& Katholieke Universiteit Nijmegen, Berg en Dal.

Petts, G.E., Gurnell, A.M., 2005. Dams and geomorphology: research progress and future directions. Geomorphology 71, 27-47.

Poff, N.L., Richter, B.D., Arthington, A.H., Bunn, S.E., Naiman, R.J., Kendy, E., Acreman, M., Apse, C., Bledsoe, B.P., Freeman, M.C., Henriksen, J., Jacobson, R.B., Kennen, J.G., Merritt, D.M., OâKeeffe, J.H., Olden, J.D., Rogers, K., Tharme, R.E., Warner, A., 2010. The ecological limits of hydrologic alteration (ELOHA): a new framework for developing regional environmental flow standards. Freshw. Biol. 55, 147-170.

Poff, N.L., Zimmerman, J.K.H., 2010. Ecological responses to altered flow regimes: literature review to inform the science and management of environmental flows. Freshw. Biol. 55, 194-205.
Polzin, M., Rood, S.B., 2000. Effects of damming and flow stabilization on riparian processes and black cottonwoods along the Kootenay River. Rivers 7 (3), 221-232.

Ribberink, J.S., Van der Sande, J.T.M., 2000. RAggradation in rivers due to overloading analytical approaches. J. Hydraul. Res. 23 (3), 273-283.

Richter, B., Richter, H., 2000. Prescribing flood regimes to sustain riparian ecosystems along meandering rivers. Conserv. Biol. 14 (5), 1467-1478.

Richter, B.D., Thomas, G.A., 2007. Restoring environmental flows by modifying dam operations. Ecology and Society 12 (1).

Rivaes, R.P., Rodríguez-González, P.M., Ferreira, M.T., Pinheiro, A.N., Politti, E., Egger, G., García-Arias, A., Francés, F., 2014. Modeling the evolution of riparian woodlands facing climate change in three European rivers with contrasting flow regimes. PloS One 9 (10), 1-14.

Rolls, R.J., Leigh, C., Sheldon, F., 2012. Mechanistic effects of low-flow hydrology on riverine ecosystems: ecological principles and consequences of alteration. Freshwater Sci. 31 (4), 1163-1186.

Rood, S.B., Mahoney, J.M., 1990. Collapse of riparian poplar forests downstream from dams in western prairies: probable causes and prospects for mitigation. Environ. Manage. 14 (4), 451-464.

Rood, S.B., Mahoney, J.M., 1995. River damming and riparian cottonwoods along the Marias River. Montana. Rivers 5 (3), 195-207.

Rood, S.B., Pan, J., Gill, K.M., Franks, C.G., Samuelson, G.M., Shepherd, A., 2008 Declining summer flows of Rocky Mountain rivers: changing seasonal hydrology and probable impacts on floodplain forests. J. Hydrol. 349, 397-410.

Santiago, J., Garcia de Jalon, D., Alonso, C., Solana, J., Ribalaygua, J., Portoles, J., Monjo, R., 2016. Brown trout thermal niche and climate change: expected changes in the distribution of cold-water fish in central Spain. Ecohydrology 9, 514-528.

Schuurman, F., Marra, W.A., Kleinhans, M.G., 2013. Physics-based modeling of large braided sand-bed rivers: Bar pattern formation, dynamics, and sensitivity. J. Geophys. Res.: Earth Surface 118, 1-19.

Staudt, A., Leidner, A.K., Howard, J., Brauman, K.A., Dukes, J.S., Hansen, L.J., Paukert, C., Sabo, J., Solorzano, L.A., 2013. The added complications of climate change: understanding and managing biodiversity and ecosystems. Front. Ecol. Environ. 11 (9), 494-501.

Ström, L., Jansson, R., Nilsson, C., 2012. Projected changes in plant species richness and extent of riparian vegetation belts as a result of climate-driven hydrological change along the Vindel River in Sweden. Freshw. Biol. 57, 49-60.

Stromberg, J., Lite, S., Dixon, M., 2010. Effects of stream flow patterns on riparian vegetation of a semiarid river: implications for a changing climate. River Res. Appl. 26, $712-729$.

Stromberg, J.C., Beauchamp, V.B., Dixon, M.D., Lite, S.J., Paradzick, C., 2007. Importance of low-flow and high-flow characteristics to restoration of riparian vegetation along rivers in arid south-western United States. Freshw. Biol. 52, 651-679.

van der Perk, J., 1996. Afferdensche en Deestsche Waarden. Inrichtingsplan (in Dutch). Tech. rep. RIZA, Lelystad.

Van Dijk, W.M., Schuurman, F., Van de Lageweg, W.I., Kleinhans, M.G., 2014. Bifurcation instability and chute cutoff development in meandering gravel-bed rivers Geomorphology 213, 277-291.

van Oorschot, M., Kleinhans, M., Geerling, G., Middelkoop, H., 2016. Distinct patterns of interaction between vegetation and morphodynamics. Earth Surf. Proc. Land. 41, 791-808.

Van Vliet, M.T.H., Franssen, W.H.P., Yearsley, J.R., Ludwig, F., Haddeland, L, Lettenmaier, D.P., Kabat, P., 2013. Global river discharge and water temperature under climate change. Global Environ. Change 23, 450-464.

Ward, J.V., Stanford, J.A., 1995. Ecological connectivity in alluvial river ecosystems and its disruption by flow regulation. Regulat. Rivers: Res. Manage. 11 (1), 105-119.

Williams, G.P., Wolman, M.G., 1984. Downstream effects of dams on alluvial rivers. Tech. rep. United states department of the interior, Washington, D.C. 